\title{
Diversity of phytoplankton species in Cheonjin Lake, northeastern South Korea
}

\author{
Han Soon Kim(D)
}

\begin{abstract}
Background: Several investigations carried out from large brackish lagoons in South Korea. However, no studies have yet examined phytoplankton in lagoons that changed to freshwater, such as Cheonjin Lake. The present study examined the algae from Cheonjin Lake.

Methods: Samples were collected at monthly inetrvals from May 2017 to April 2018, from the surface layer using a plankton net (mesh size $20 \mu \mathrm{m}$ ), and sequeezing submerged macrophytes. Microscopic examinations were conducted at a magnification of 200 to 1000x using a Zeiss microscope (Axio Imager. A2), and photographs were taken with an AxioCam HRC camera. Silica-scaled samples of Chrysophyta for SEM were placed on coverglass, air dried, coated with gold, and then examined with a Hitachi SV8220 SEM.

Results: A total of 376 taxa from six major algal groups (Chlorophyta, Chrysophyta, Euglenophyta, Cyanophyta, Dinophyta, and Cryptophyta) were identified. Among these algae, 28 taxa of desmids, 9 taxa of Euglenophyceae, 4 taxa of Chlorophyceae, 2 taxa of Chrysophyceae, and 1 taxon of Xanthophyceae are reported for the first time in Korea. A new species, Cosmarium hexagonum sp. nov was described. The phytoplankton communities were characterized by an abundance of Desmids (within Charophyceae) accounted for 148 taxa from 22 genera. Species richness were particularly high in the Autumn.

Conclusion: In this study, a total 376 taxa of 148 desmids (Charophyceae), Chlorophyceae (103 taxa), Chrysophyceae (53 taxa), Euglenophyta (49 taxa), Dinophyta (8 taxa), and Cryptophyta (2 taxa) were identified from Cheonjin Lake. Twenty-eight taxa of desmids including a new species (Cosmarium hexagonum sp. nov.), 9 taxa of Euglenophyceae, 4 taxa of Chlorophyceae, 2 taxa of Chrysophyceae, and 1 taxon of Xanthophyceae were newly recorded in Korea.
\end{abstract}

Keywords: Lagoon, Phytoplankton, Desmids, For the first time in Korea, New species

\section{Background}

Many investigations of freshwater algae in different regions of Korea have examined reservoirs, dam lakes, swamps, lagoons, streams, and rivers (Chung et al. 1968; Chung 1975, 1976, 1979; Chung et al. 1972a, 1972b; Chung and Lee 1986; Wui and Kim 1987a, 1987b; Kim and Chung 1993a, 1993b; Kim 1996, 1997; Kim et al. 1995; Kim et al. 2007; Kim et al. 2009; Kim 2013a, b, c, 2014a, b). There are currently about 3888 known taxa of freshwater algae in Korea, and these taxa are in Cyanophyta (343 taxa), Chlorophyta (1542 taxa), Ochrophyta (167 taxa), Cryptophyta (12 taxa), Euglenophyta (329

Correspondence: kimhsu@knu.ac.k

School of Life Sciences, Kyungpook National University, Daegu 702-701, Korea

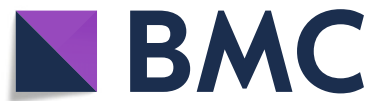

taxa), and Bacillariophyceae (1495 taxa) (Kim 2015, Lee and Joh 2015, Lee and Kim 2015, Lee and Kim 2015). Most previous freshwater floristic and taxonomic studies of algae in Korea have examined lowland habitats, such as reservoirs, dam lakes, swamps, ponds, streams, and rivers, and only a few have examined highland wetlands.

There are 18 lagoons in Korea, and these are concentrated on the middle-eastern coast of the Korean peninsula (Gangwon Province). More than half of these lagoons were previously freshwater lakes, or seriously damaged by road construction, reclamation to cultivated land, or development. Some previous investigations have examined phytoplankton from large brackish lagoons in South Korea (Cho and Park 1969; Hong et al. 1969; Cho et al. 1975; Lee et al. 2000; Moon and Lee 2002; Heo et al.

C The Author(s). 2018 Open Access This article is distributed under the terms of the Creative Commons Attribution 4.0 International License (http://creativecommons.org/licenses/by/4.0/), which permits unrestricted use, distribution, and reproduction in any medium, provided you give appropriate credit to the original author(s) and the source, provide a link to the Creative Commons license, and indicate if changes were made. The Creative Commons Public Domain Dedication waiver (http://creativecommons.org/publicdomain/zero/1.0/) applies to the data made available in this article, unless otherwise stated. 


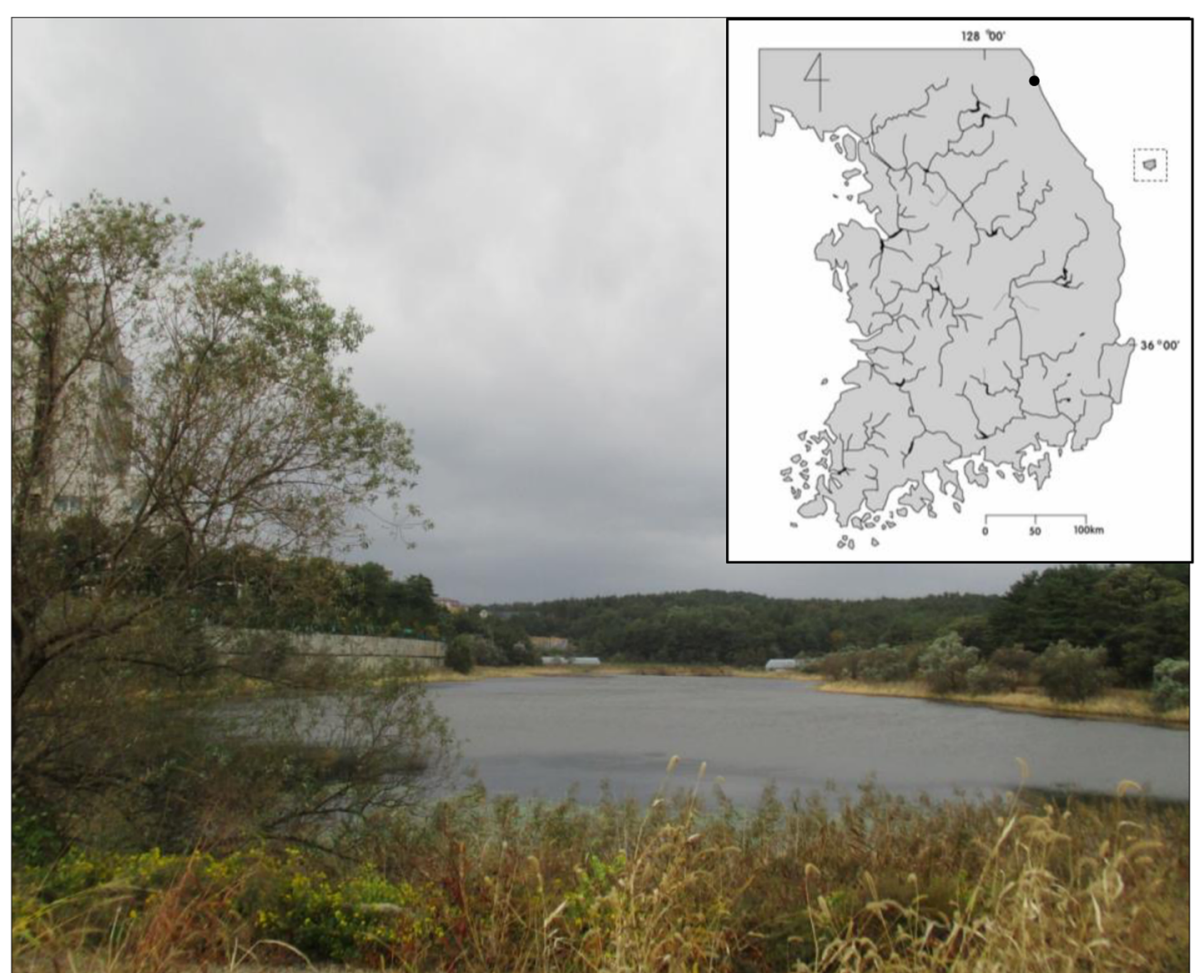

Fig. 1 Map showing the Cheonjin Lake located in northeastern South Korea

2004; Kwon et al. 2005). However, no studies have yet examined phytoplankton in lagoons that changed to freshwater, such as Cheonjin Lake.

Desmids, a group of green algae within the Charophyceae, occur in diverse freshwater habitats, most of which have low salinity and hence low specific conductivity. This includes reservoirs, lakes, ponds, ditches, and bogs, but desmids are especially abundant in acid bogs, in association with Sphagnum and Utricularia species (Brook 1981; Brook and Williamson 2010).

The present study examined the phytoplankton from Cheonjin Lake, formerly a small lagoon, but now a freshwater lake in northeastern South Korea.

\section{Methods}

\section{Study site}

Cheonjin Lake is located in the near the coastal region of South Korea (Fig. 1) at latitude $38^{\circ} 15^{\prime} 14^{\prime \prime} \mathrm{N}$ and longitude $128^{\circ} 33^{\prime} 22^{\prime \prime}$ E. This lake was originally a brackish lagoon connected to the East Sea, but it changed to a freshwater lake following road construction. Over time, it was polluted and reduced in size because of various development projects and reclamation for farmland. The surface area is about $0.28 \mathrm{~km}^{2}$ and the depth is about $1.5 \mathrm{~m}$. The vegetation is abundant and mainly consists of reeds (Poales) and water lilies (Nymphaea spp.).

\section{Sample collection and identification}

Samples were collected at monthly intervals from May 2017 to April 2018, from the surface layer using a plankton net (mesh size $20 \mu \mathrm{m}$ ), and by squeezing submerged macrophytes. All living materials were immediately examined, and after an initial examination, materials were fixed with $5 \%$ formalin for permanent preservation and detail identification. Microscopic examinations were conducted at a magnification of 200 to $1000 \times$ using a Zeiss microscope (Axio Imager.A2), and photographs were taken with an AxioCam HRC camera (Carl Zeiss). Silica-scaled samples of Chrysophyta for scanning electron microscopy (SEM) were placed on coverglass, air dried, coated with gold, and then examined with a Hitachi SV8220 SEM. Bacillariophyceae were not examined. The materials were deposited at the Department of Biology, Kyungpook National University.

\section{Results}

\section{Algae in Cheonjin Lake}

I identified 376 taxa from seven major algal groups in Cheonjin Lake. There were 148 desmids (Charophyceae), the most abundant group. This was followed by Chlorophyceae (103 taxa), Chrysophyta (53 taxa), Euglenophyta (49 taxa), Cyanophyta (13 taxa), Dinophyta (8 taxa), and Chryptophyta (2 taxa) (Table 1). There were 28 species of desmids new to Korea, and one newly identified species- 
Table 1 A list of phytoplankton species of the Cheonjin Lake. * indicates new to Korea, ${ }^{* *}$ indicates new to Korean peninsula Division Cyanophyta Class Cyanophyceae

Anabaena sp.
Aphanothece microscopica
Chroococcus minutus
Cyanothece aeruginosa
Geitlerinema splendidum
Hapalosiphon hibernicus
Merismopedia glauca
Merismopedia tenuissima
Oscillatoria agardhii
Oscillatoria princeps
Oscillatoria tenuis
Phormidium simplicissimum
Scytonema sp.

Division Chlorophyta Class Chlorophyceae

Ankistrodesmus densus

Ankistrodesmus faciculatus

Ankistrodesmus falcatus

Ankistrodesmus fusiformis

Ankistrodesmus spiralis

Asterococcus superbus

Botryococcus braunii

Botryococcus sudetica

Bulbochaete sp.

Chaetophora pisiformis.

Chaetosphaeridium globosum

Chlamydomonas sp.

Coelastrum asteroideum

Coelastrum indicum

Coelastrum microporum

Coelastrum probocideum

Coelastrum pulchrum

Coelastrum sphaericum

Crucigenia fenestrata

Crucigenia tetrapedia

Crucigeniella apiculata

Crucigeniella crucifera

Crucigeniella pulchra

Crucigeniella quadrata

Crucigeniella rectangularis

Diacanthos belenophorus

Dictyosphaerium ehrenbergianum

Dictyosphaerium pulchellum

Dictyosphaerium sphagnale

Dimorphococcus lunatus

Table 1 A list of phytoplankton species of the Cheonjin Lake. * indicates new to Korea, ${ }^{* *}$ indicates new to Korean peninsula (Continued)

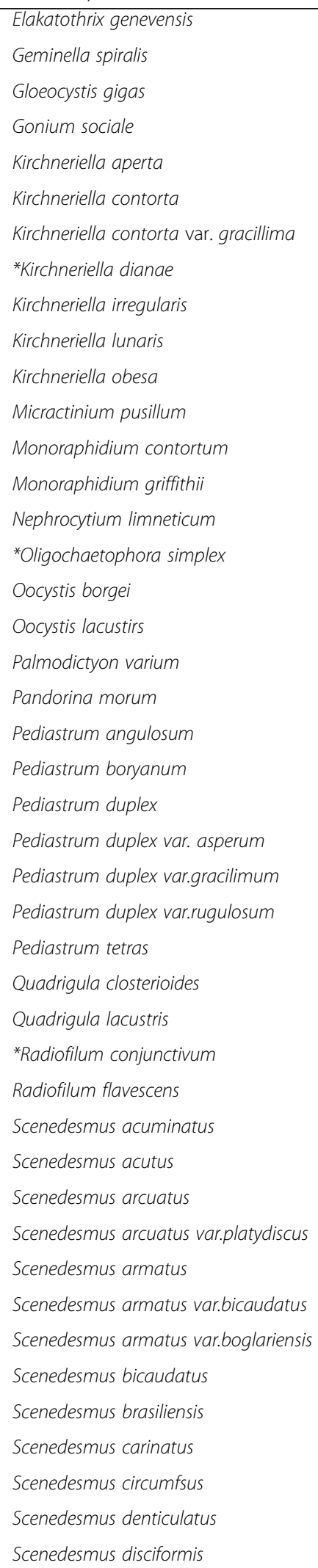


Table 1 A list of phytoplankton species of the Cheonjin Lake. * indicates new to Korea, ${ }^{* *}$ indicates new to Korean peninsula (Continued)

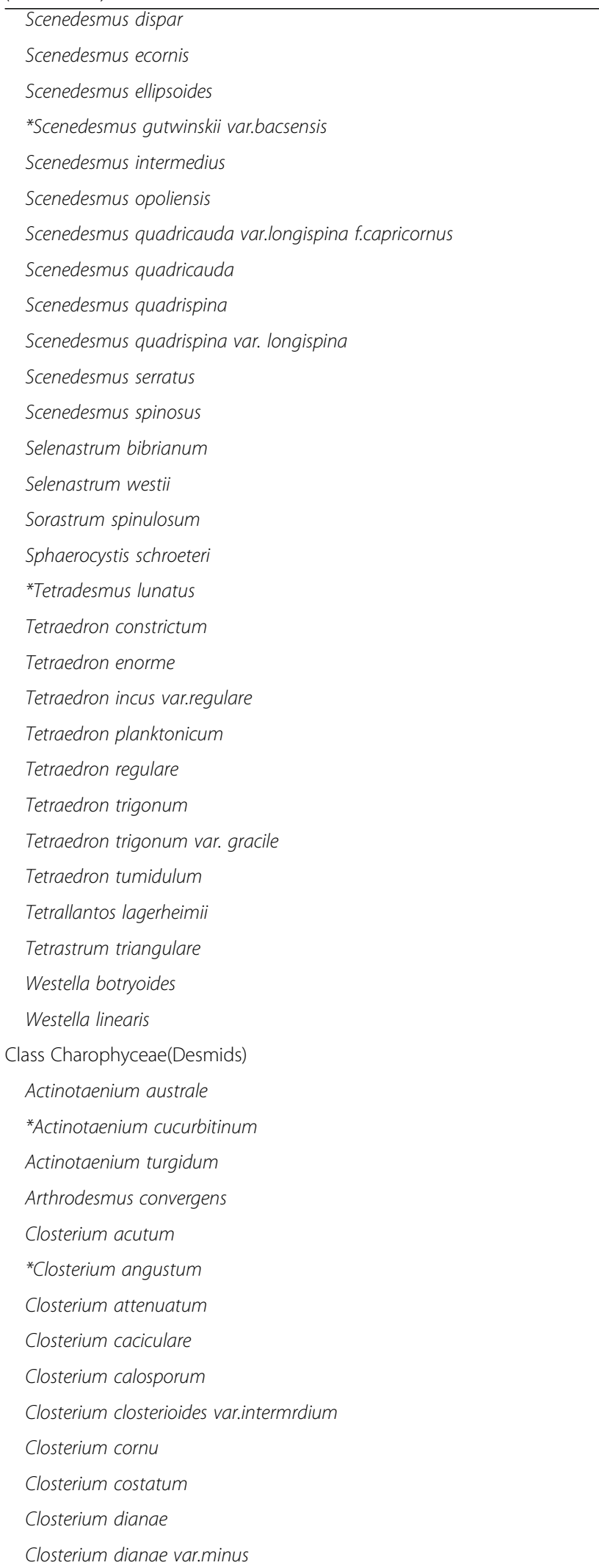

Table $1 \mathrm{~A}$ list of phytoplankton species of the Cheonjin Lake. * indicates new to Korea, ${ }^{* *}$ indicates new to Korean peninsula (Continued)

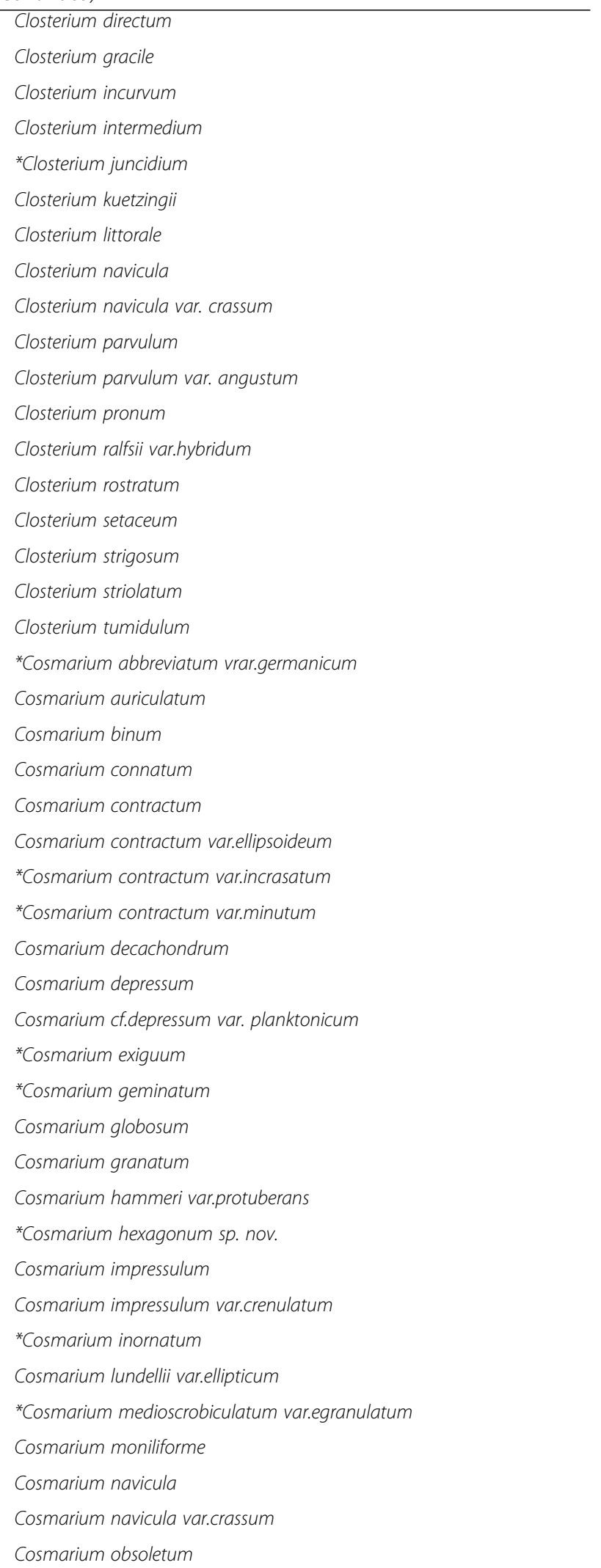


Table 1 A list of phytoplankton species of the Cheonjin Lake. * indicates new to Korea, ${ }^{* *}$ indicates new to Korean peninsula (Continued)

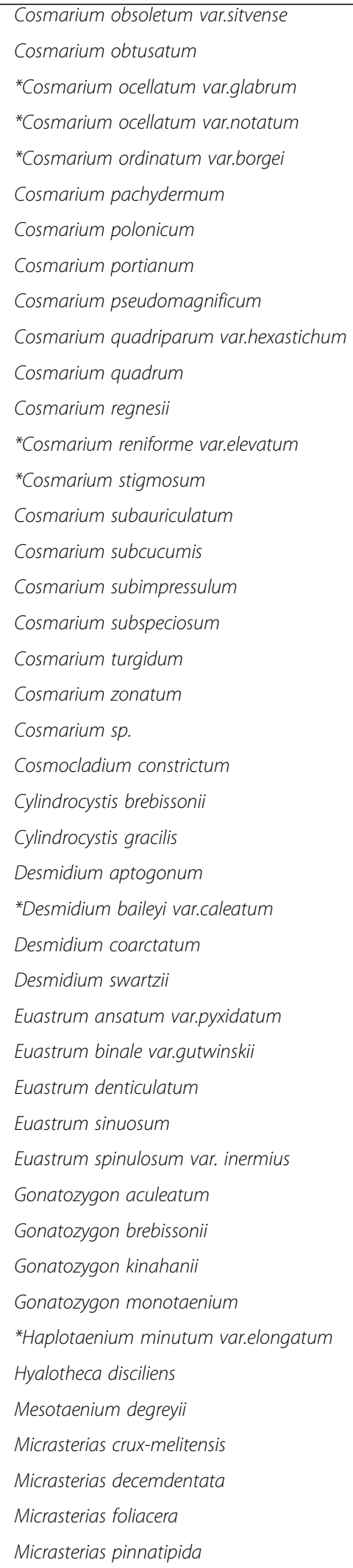

Table 1 A list of phytoplankton species of the Cheonjin Lake. * indicates new to Korea, ${ }^{* *}$ indicates new to Korean peninsula (Continued)

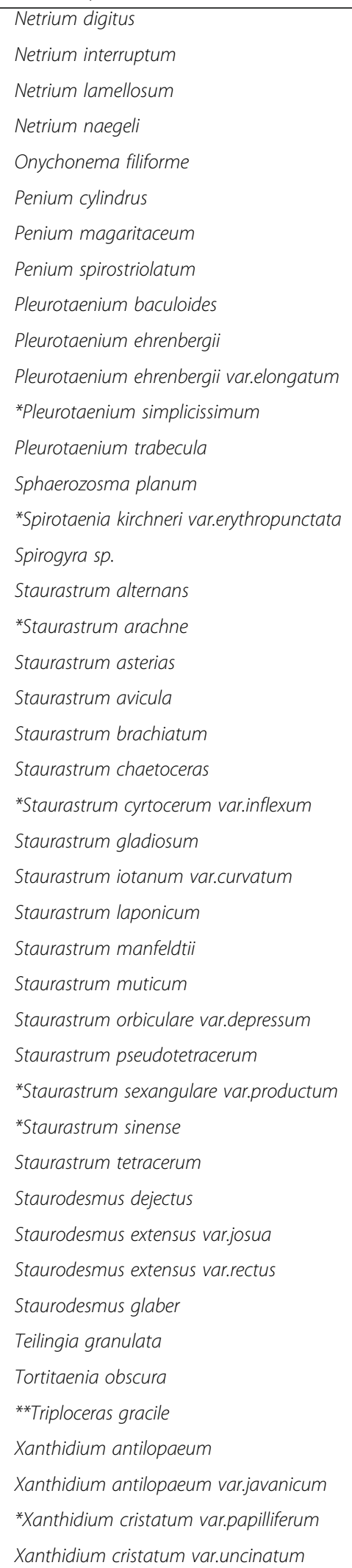


Table 1 A list of phytoplankton species of the Cheonjin Lake. * indicates new to Korea, ${ }^{* *}$ indicates new to Korean peninsula (Continued)

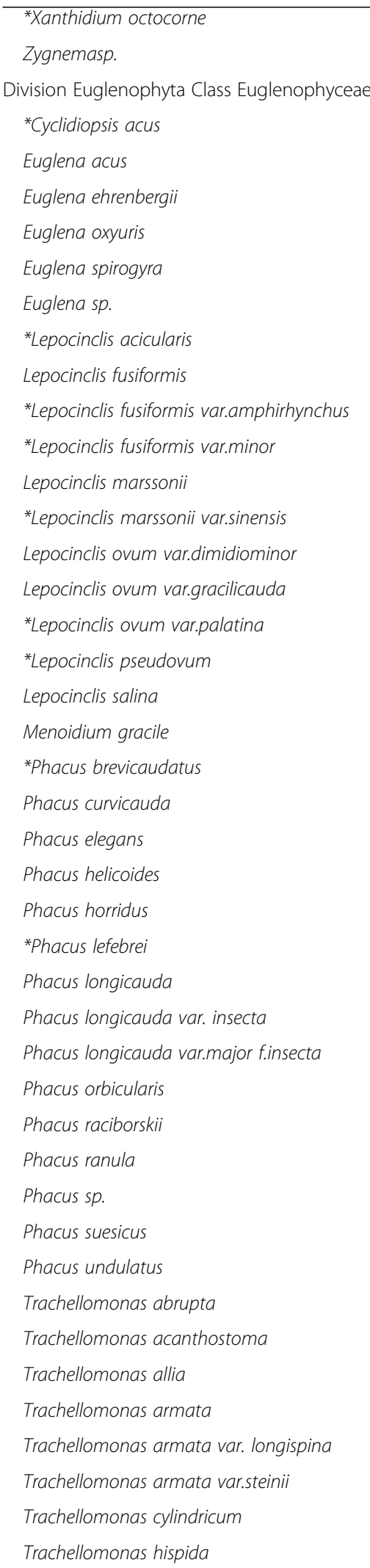

Table 1 A list of phytoplankton species of the Cheonjin Lake. * indicates new to Korea, ${ }^{* *}$ indicates new to Korean peninsula (Continued)

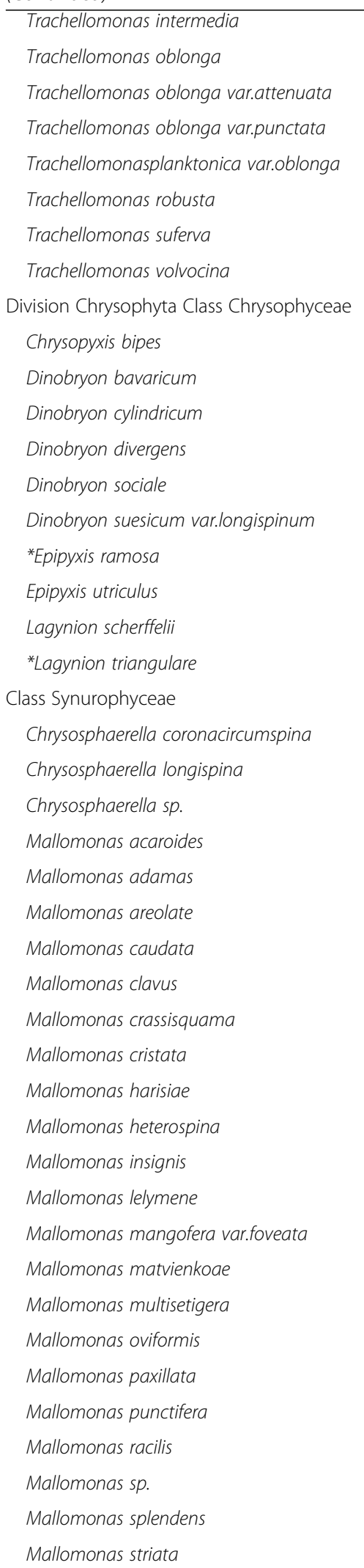


Table 1 A list of phytoplankton species of the Cheonjin Lake. * indicates new to Korea, ${ }^{* *}$ indicates new to Korean peninsula

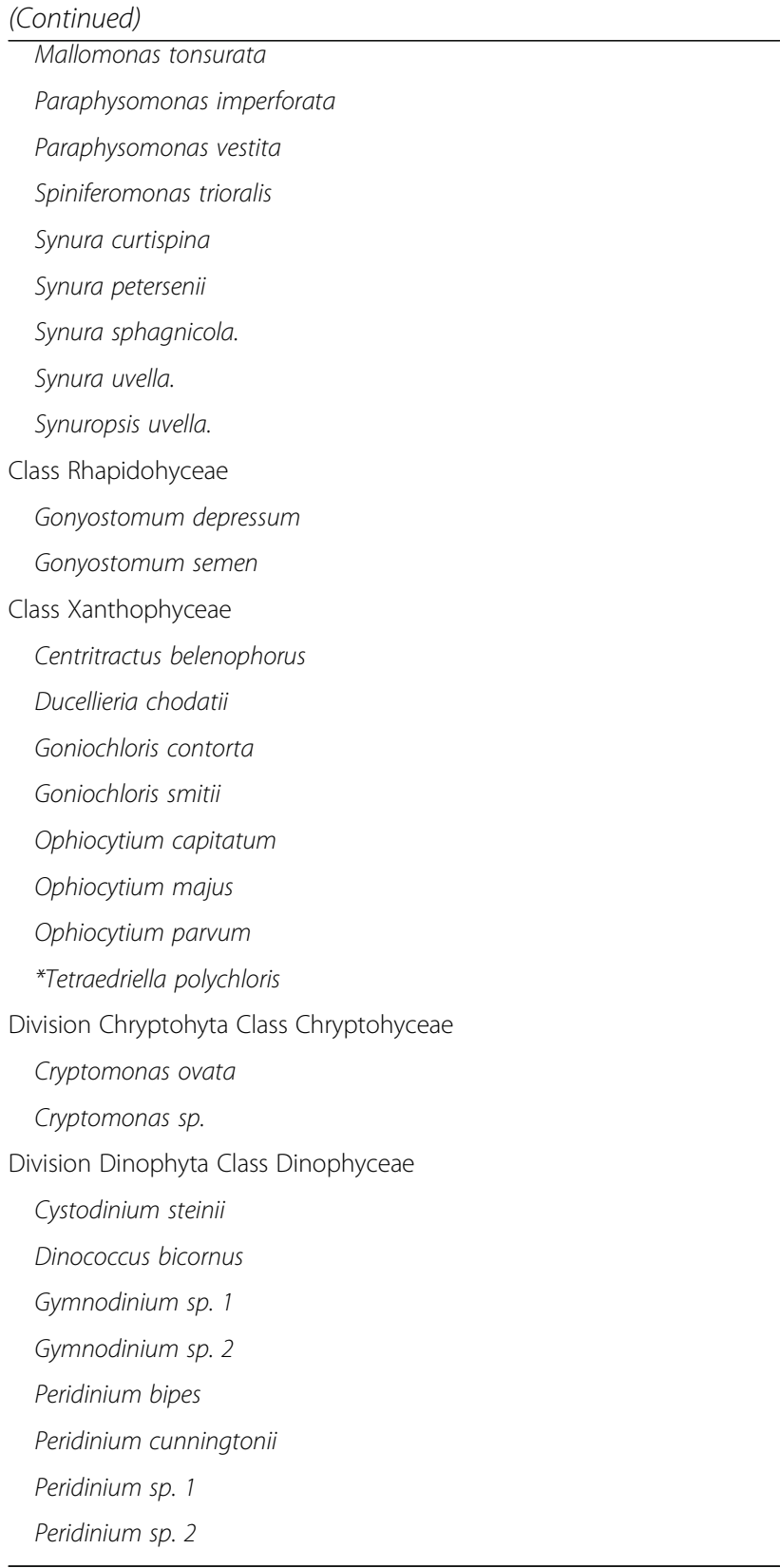

C. hexagonum sp. nov.. There were also 9 species of Euglenophyceae, 4 species of Chlorophyceae, 2 species of Chrysophyceae, and 1 species of Xanthophyceae that were new to Korea. I photographed and briefly discussed the taxonomy of all species (Plates 1, 2, 3, 4, 5, 6, and 7), including the one newly identified species of desmids.

Table 1 lists all algal species from Cheonjin Lake. Cheonjin Lake had abundant Charophyta, especially desmids, and significantly greater phytoplankton richness during the autumn (September and October; 180 taxa) than during the cold season (December to March; 44 to 54 taxa) (Fig. 2).

\section{Chlorophyta}

I identified 103 taxa in the Chlorophyceae, 4 of which are new to Korea. Also, we identified 148 taxa in the Charophyceae, and desmids were the most abundant and widely distributed throughout the year. We identified one new species-Cosmarium hexagonum sp. nov.-and 27 taxa that were new to Korea. Notably, we recorded Triploceras gracile for the first time in the Korean peninsula.

\section{Systematic enumeration and descriptions Oligochaetophora simplex (West) G.S. West (Plate 1, Fig. 1)} John et al. 2011, p. 567, Pl. 135, Fig. G.

Thallus composed of 2-6 loose cells enclosed within a gelatinous envelope. Cells $12-15 \mu \mathrm{m}$ in diameter, spherical or ovoid, with thin walls, each with 2-4 flexuous setae $(50-210 \mu \mathrm{m}$ long).

\section{Parallela transversalis (Brébisson) Novis, M. Lorenz, Broady \& E.A. Flint (Plate 1, Fig. 5) (Syn.: Radiofilum irregulare (Wille) Brunnthaler)}

Prescott 1962, p. 104, Pl. 7, Figs. 3-5.

Thallus unbranched and uniseriate, short filaments enclosed by a mucilaginous envelop; cells compressed and lenticular, with walls divided into two distinct halves, and adjoined in midregion by a prominent transverse ring. Cell diameter $15-20 \mu \mathrm{m}$, length $4-8 \mu \mathrm{m}$. Cells very similar to $R$. conjunctivum, but compressed and lenticular.

\section{Kirchneriella dianae (Bohl.) Comas (Plate 1, Fig. 2)} Yamagishi and Akiyama 1989, 9. 47; Komárek and Fott 1983, p. 668, Pl. 187, Fig. 1.

Colony free-floating, with $4,8,16$, or more cells densely arranged, enclosed by a hyaline mucilaginous sheath; cells flattened, strongly curved, crescent-shaped, with pointed ends, sometimes almost touching, and frequently slightly twisted; single chloroplast with a pyrenoid fills the entire cell. Cell length 10-15 $\mu \mathrm{m}$, width 3$5 \mu \mathrm{m}$.

\section{Tetradesmus lunatus Koršikov (Plate 1, Fig. 4)}

Komárek and Fott 1983, p. 806, Pl. 223, Fig. 5.

Coenobium with 4 cells, quadrate arrangement in two planes, and parallel longitudinal axes; cells lunate, adjoined lengthwise along 1/3 of lateral walls; outer wall concave, apices narrowed. Cell length 17-18 $\mu \mathrm{m}$, breadth $3-5 \mu \mathrm{m}$. 


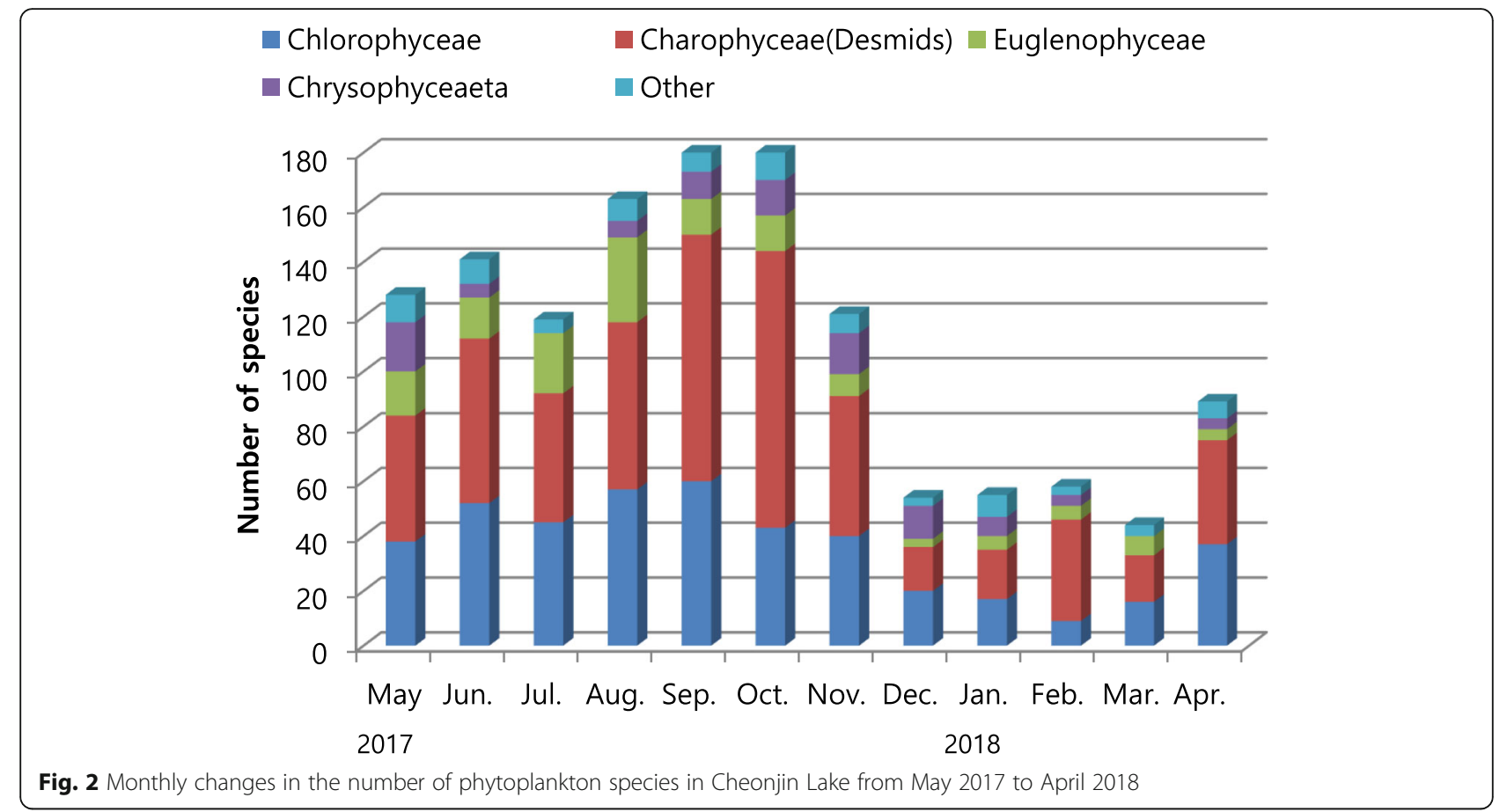

Spirotaenia kirchneri var. erythropunctata (Lagerh.) Krieger (Plate 2, Figs. 21 and 22)

Brook and Williamson 2010, p. 71. Pl. 27, Figs. 2 and 3.

Cell 6-8 times as long as broad; small reddish granules between ends of chloroplast and apices; chloroplast single, 2-3 turns of the cells. Cell length 22-27 $\mu \mathrm{m}$, breadth $3-5 \mu \mathrm{m}$.

Closterium angustatum Kützing ex Ralfs (Plate 5, Figs. 1-3) Coesel and Meesters K(J). 2007, p. 39, Pl. 25, Fig. 4; Brook and Williamson 2010, p. 204, Pl. 85, Figs. 1-7, Pl. 86, Figs. 1-4.

Cell narrow, elongated, about 12-20 times longer than broad, slightly curved or straight, central margins nearly parallel, each apex slightly attenuated; cell ends slightly swollen and capitate; cell walls having girdle bands and a broad costa $(2-3$ striation/10 $\mu \mathrm{m})$. Cell length 250$500 \mu \mathrm{m}$, breadth $19-28 \mu \mathrm{m}$, breadth of apex $4-6 \mu \mathrm{m}$.

\section{Closterium juncidum Ralfs (Plate 5, Figs. 4 and 5)}

Coesel and Meesters K(J). 2007, p. 45, Pl. 26, Figs. 2-3; Brook and Williamson 2010, p. 219, Pl. 96, Figs. 1-8, Pl. 97, Figs. 1-10, Pl. 98, Figs. 1-8.

Cell narrow, slender, about 20-35 times longer than broad, almost straight and fusiform, slightly curved and attenuated near the apex, apices obliquely truncately rounded; cell walls with girdle bands, finely striate (1015 striation $/ 10 \mu \mathrm{m})$. Cell length $200-220 \mu \mathrm{m}$, breadth 9-11 $\mu \mathrm{m}$, breadth of apex 4-6 $\mu \mathrm{m}$.
Haplotaenium minutum var. elongatum (West \& West) Cedergren (Plate 5, Figs. 6 and 7)

(Syn.: Pleurotaenium minutum var. elongatum (West \& West) Cedergren)

Prescott et al. 1975. p. 123. Pl. 39, Fig. 61.

Cell slender, very long, about 25-30 times longer than broad, slightly attenuated at both ends; semicells without basal inflation, both apexes smooth and truncately rounded. Cell length 250-300 $\mu \mathrm{m}$, breadth 9-12 $\mu \mathrm{m}$.

\section{Pleurotaenium simplicissimum Grönblad (Plate 5, Figs. 8-10)}

Yamagishi and Akiyama 1986, 5: 73; Coesel and Meesters K(J). 2007, p. 68, Pl. 36, Figs. 1-3.

Cell cylindrical, elongate, about 18-24 times longer than broad, not tapering toward the apices; semicells with a very slightly basal inflation, both apexes truncate, with a whorl of tiny granules, 8-12 visible in face view. Cell length $600-800 \mu \mathrm{m}$, breadth $31-$ $42 \mu \mathrm{m}$.

\section{Actinotaenium cucurbitinum (Bisset) Teiling (Plate 2, Fig. 1)} (Syn.: Cosmarium cucurbitinum (Bisset) Lütkemüller)

Hirano 1955, p. 80. Pl. 16, Fig. 23; Prescott et al. 1981, p. 11, Pl. 151, Figs. 1-3.

Cell medium-size, about 2-2.5 times longer than broad, ellipsoid to broadly fusiform, median constriction shallow, apices rounded; cell walls with distinct pores; chloroplast star shaped. Cell length $60-70 \mu \mathrm{m}$, breadth 25-30 $\mu \mathrm{m}$, isthmus 22-28 $\mu \mathrm{m}$. 

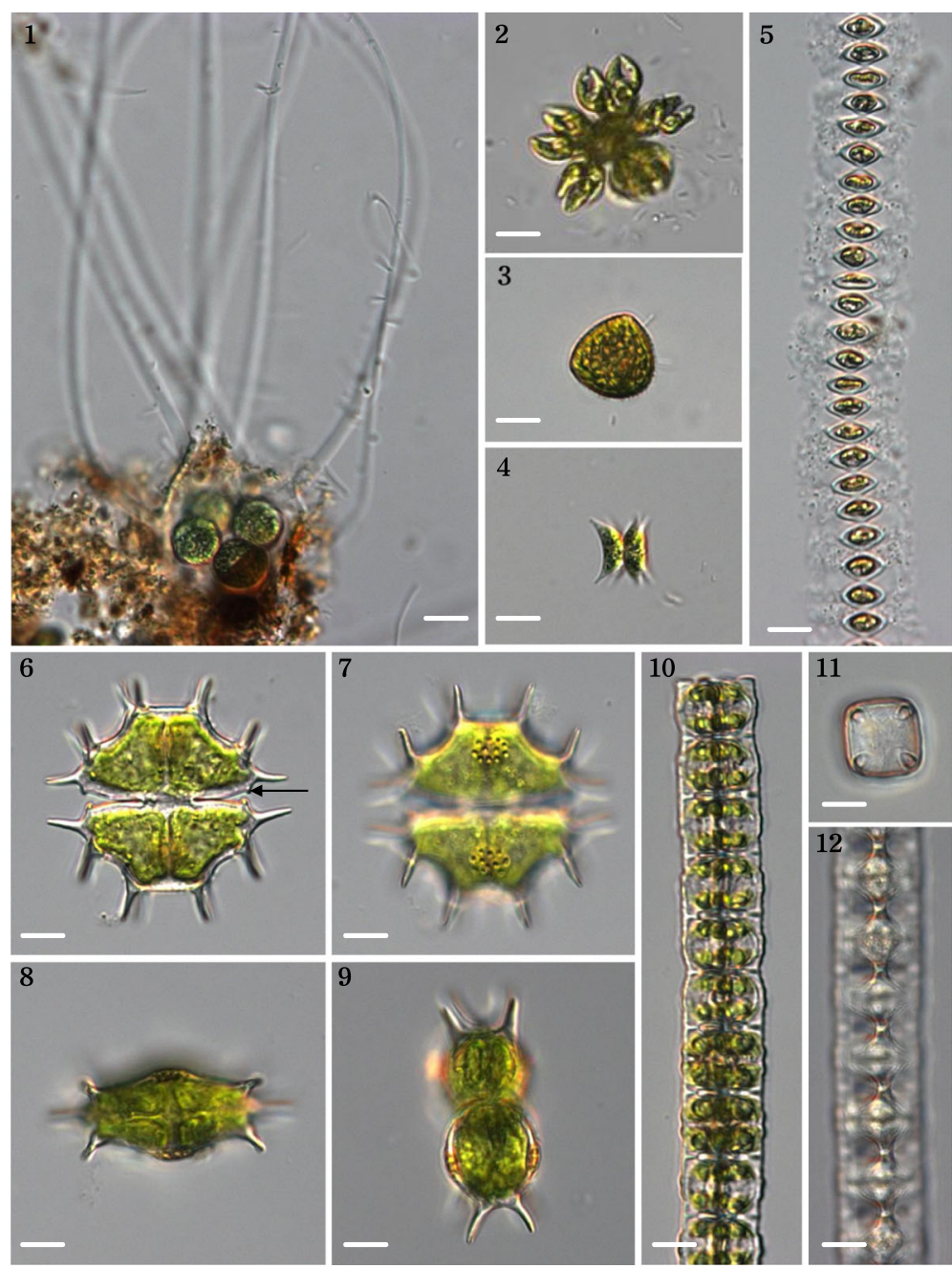

Plate 1 Fig. 1 Oligochaetophora simplex. 2 Kirchneriella dianae. $\mathbf{3}$ Tetraedriella polychloris. 4 Tetradesmus lunatus. 5 Parallela transversalis. 6-9 Xanthidium cristatum var. papilliferum. 10-12 Desmidium baileyi var. caleatum. Scale bars here and below: $10 \mu m$

Cosmarium hexagonum sp. nov. Han Soon Kim (Plate 2,

\section{Figs. 14 and 15)}

Cell small, about as long as broad, median constriction deep, sinus open outward; semicells rhomboid, lower lateral margins rounded, slightly convex, median part slightly pronounced, apex straight, symmetrically elliptic, poles pronounced or rounded; in vertical view semicell octagonal shape, with a prominent conical tumor in the midregion on either side, lateral margins straight to slightly retuse. Cell length 25-27 $\mu \mathrm{m}$, breadth 24-25 $\mu \mathrm{m}$, isthmus 5-6 $\mu \mathrm{m}$.

This species is similar to $C$. praecisum Borge, $C$. polygonatum Halász, $C$. polygonum var. polygonum $\mathrm{f}$. rectum Bicudo and $C$. polygonum var. hexagonum Grönblad in hexagonal semicell shape and having tubercles in median region of semicell. However, $C$. hexagonum sp. nov. is distinguished from the others by the more large size, more hexagonal outline of the semicells and octagonal shape with retuse margins and more conical tumor in the median region of semicell in vertical view (Table 2).

Type locality: Cheonjin Lake, Kangwon Province, Goseong

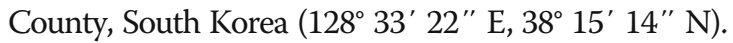

Holotype: Figures 16 and 17 from materials collected on 1 May 2017 deposited at the National Nakdong River Institute of Biological Resources (NNIBR) and Department of Biology, Kyungpook National University.

\section{C. cf. depressum var. planktonicum Reverdin (Plate 2, Figs. 19 and 20)}

Croasdale and Flint 1988. p. 65. Pl. 34, Figs. 7 and 8; Yamagishi and Akiyama 1997. 18. 24.

Cell small, slightly broader than long, median constriction deep, sinus narrowly open, enclosed in thick mucilaginous sheath, with numerous radiating fibrils; semicells elliptic, upper margins straight to slightly convex, elliptic with poles broadly rounded in vertical 


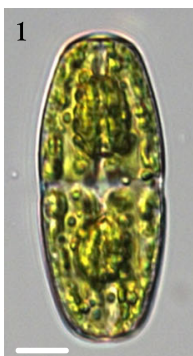

5

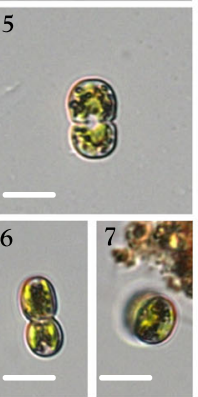

14
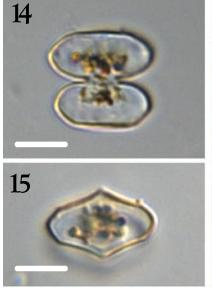

19
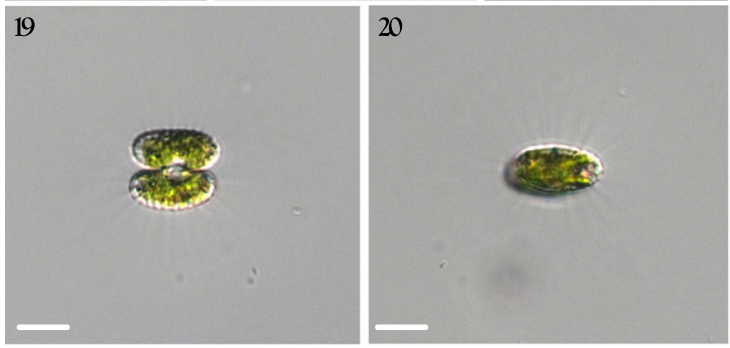

Plate 2 Fig. 1 Actinotaenium cucurbitinum. 2-4 Cosmarium geminatum. 5-7 C. exigum. 8-10 C. ocellatum var. glabrum. 11-13 C. ocellatum var. notatum. 14-15 C. hexagonum sp. nov. 16-18 C. pseudoornatum. 19-20 C. cf. depressum var. planktonicum. 21-22 Spirotaenia kirchneri var. erythropunctata
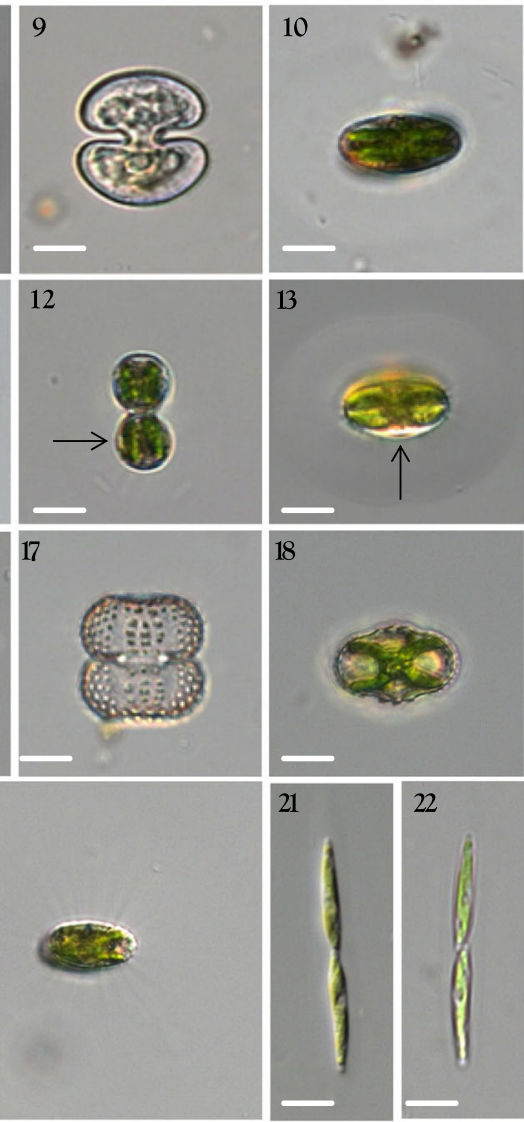
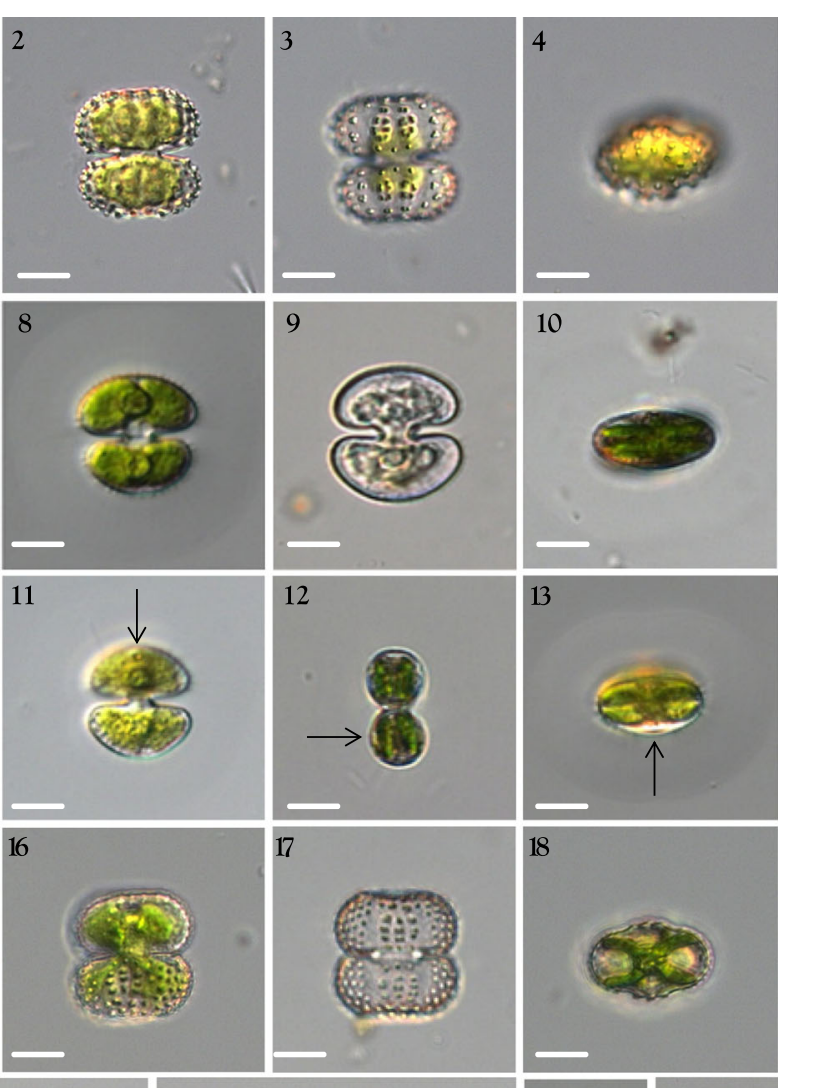

view; cell wall punctate. Cell length $15-17 \mu \mathrm{m}$, breadth 17-20 $\mu \mathrm{m}$, isthmus 4-5 $\mu \mathrm{m}$. This specimen is similar to $C$. depressum var. planktonicum. However, it differing from the nominate variety by elliptic shape compare to trapeziform of semicell in front view.

\section{Cosmarium abbreviatum var. germanicum (Raciborski) Krieger \& Gerloff (Plate 3, Figs. 4-6)}

Hirano 1957, p. 159. Pl. 25, Fig. 38; Krieger and Gerloff 1969, p. 242, Pl. 42, Fig. 16.

Cell small, as long as broad, median constriction deep, sinus linear, closed; semicells subhexagonal, lateral, upper margins slightly concave, elliptic with poles 

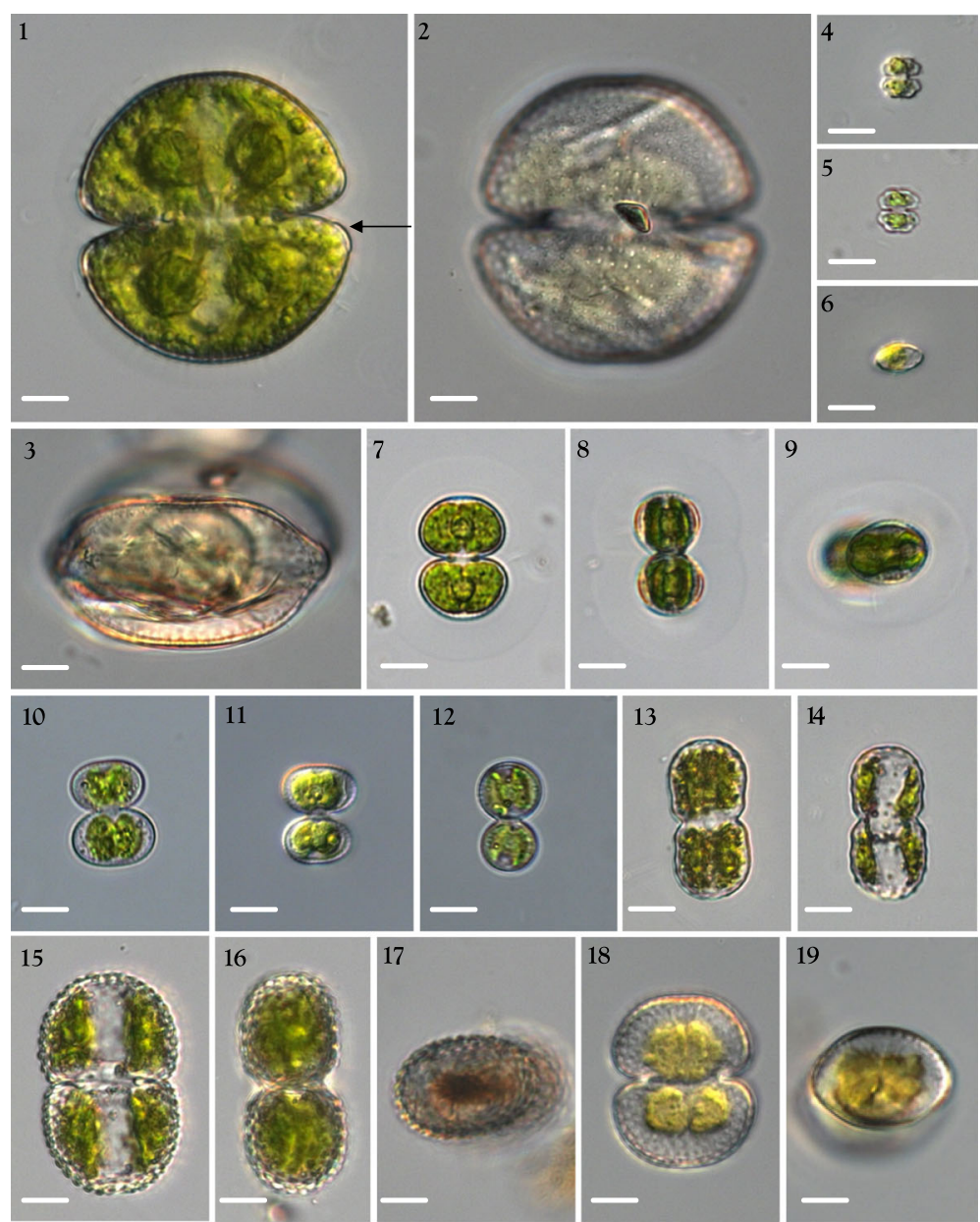

Plate 3 Figs. 1-3 Cosmarium medioscrobiculatum var. egranulatum. 4-6 C. abbreviatum var. germanicum. 7-9 C. contractum var. incrassatum. 1012 C. contractum var. minutum. 13, 14 C. inornatum. 15-17 C. reniforme var. elevatum. 18, 19 C. stigmosum

\section{Cosmarium contractum var. minutum Scott \& Prescott}

(Plate 3, Figs. 10-12)

Prescott et al. 1981. p. 108. Pl. 175, Figs. 16 and 17.

Cell small, less than $28 \mu \mathrm{m}$ long, about 1.3-1.4 times longer than broad, median constriction deep, sinus acutely open, often enclosed by thick gelatinous sheath; semicells broadly elliptic in vertical view, circular in lateral view. Cell length $22-26 \mu \mathrm{m}$, breadth $17-21 \mu \mathrm{m}$, isthmus $4-5 \mu \mathrm{m}$.

\section{Cosmarium exiguum Archer (Plate 2, Figs. 5-7)}

Prescott et al. 1981. p. 136. Pl. 206, Fig. 4.

Cell small, about two times as long as broad, median constriction deep, sinus acutely open, closed outwardly; semicells subquadrate with rounded angles, lateral margins and apex almost straight, elliptic in vertical view, broadly elliptic in lateral view; cell wall smooth; Cell length 14-29 $\mu \mathrm{m}$, breadth 7-15 $\mu \mathrm{m}$, isthmus $3-5 \mu \mathrm{m}$.
Cosmarium geminatum P. Lundell (Plate 2, Figs. 2-4)

Dillard 1991: 73. Pl. 30, Fig. 4; Coesel and Meesters K(J). 2007: 118. Pl. 69, Figs. 26 and 27.

Cell small, subcylindrical, as long as broad, median constriction deep, sinus acutely open and rounded at extremity; semicells transversely elliptic, apical margin flat to slightly convex, lateral margins convex, apical and basal angles rounded, elliptic in vertical view with a pair of small emarginated warts at middle on each side, nearly circular with granules in lateral view; cell wall granulate, midregion with a pair of 4 small granules transversely disposed. Cell length 26-27 $\mu \mathrm{m}$, breadth 25-27 $\mu \mathrm{m}$, isthmus 7-9 $\mu \mathrm{m}$.

Cosmarium inornatum Joshua (Plate 3, Figs. 13 and 14) Yamagishi and Akiyama 1987. 7. 19.

Cell medium in size, subcylindrical, about two-times longer than broad, median constriction very shallow, sinus widely open; semicells subquadrate, apex convex and undulate, apical angle broadly rounded, lateral margins 

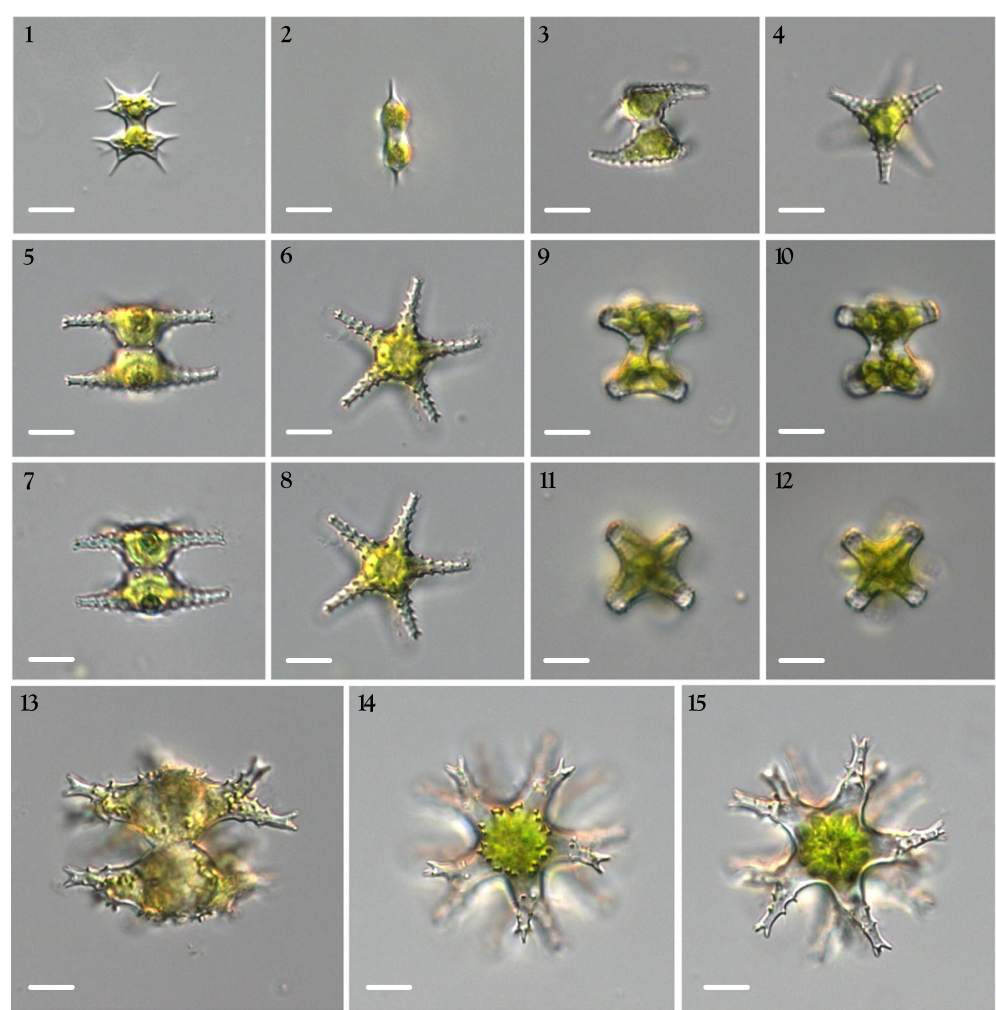

Plate 4 Figs. 1, 2 Xanthidium octocorne. 3, 4 Staurastrum cyrtocerum var. inflexum. 5-8 S. arachne. 9-12 S. sinense. 13-15 S. sexangulare var. productum

parallel, lower lateral undulations rather larger than upper undulation, broadly elliptic to nearly circular in vertical view; cell wall with regularly disposed granules. Cell length 34-36 $\mu \mathrm{m}$, breadth $18-20 \mu \mathrm{m}$, isthmus $11.5-13 \mu \mathrm{m}$.

\section{Cosmarium medioscrobiculatum W. \& G.S. West (Plate 3,}

Figs. 1-3)

(Syn.: Cosmarium medioscrobiculatum var. egranulatum Gutwinskii)

Scott and Prescott 1961. p. 63. Pl. 26, Fig. 3; Yamagishi and Akiyama 1987. 7. 20.

Cell large, slightly longer than broad, median constriction deep, sinus narrowly linear; semicells semicircular to trapeziform, apical margin nearly flat to convex, basal angles broadly rounded, with thickened wall (Plate 3, Fig. 1, arrow), hexagonal in vertical view; cell wall with minute granules and about 20 scrobiculations. Cell length $68-70 \mu \mathrm{m}$, breadth $60-$ $65 \mu \mathrm{m}$, isthmus $24-26 \mu \mathrm{m}$. Our isolates much larger than type specimen.

Cosmarium ocellatum var. glabrum Hinode (Plate 2, Figs. 8-10)

Yamagishi and Akiyama 1984. 2. 15.
Cell small, as long as broad, median constriction deep, sinus linear, rounded at extremity; semicells semielliptic or semicircular, basal angle rounded, apex scarcely flattened, elliptic with poles broadly rounded in vertical view, circular in lateral view; cell wall smooth or finely punctuate, without central scrobiculation. Cell length 25-27 $\mu \mathrm{m}$, breadth $23-25 \mu \mathrm{m}$, isthmus $5-6 \mu \mathrm{m}$.

\section{Cosmarium ocellatum var. notatum (Nordstedt) Krieger \& Gerloff (Plate 2, Figs. 11-13) \\ (Syn.: Cosmarium notatum (Grönblad) Coesel)}

West and West 1912, p. 3, Pl. 117, Figs. 6-10; Coesel and Meesters K(J). 2007, p. 128, Pl. 76, Figs. 4 and 5.

Cell small, slightly longer than broad, median constriction deep, sinus linear, apex dilated; semicells subsemicircular, basal angle rounded, elliptic with poles broadly rounded in vertical view, circular in lateral view; cell wall fine punctuate, with central scrobiculation (Plate 2, Fig. 11, arrow), wall in midregion strongly thickened and often brown (Plate 2, Fig. 12, arrow). Cell length $24-25 \mu \mathrm{m}$, breadth $21-23 \mu \mathrm{m}$, isthmus $4-5 \mu \mathrm{m}$.

Cosmarium pseudoornatum Eichler \& Gutwinski (Plate 2, Figs. 16-18)

Prescott et al. 1981. p. 239. Pl. 256, Fig. 6. 


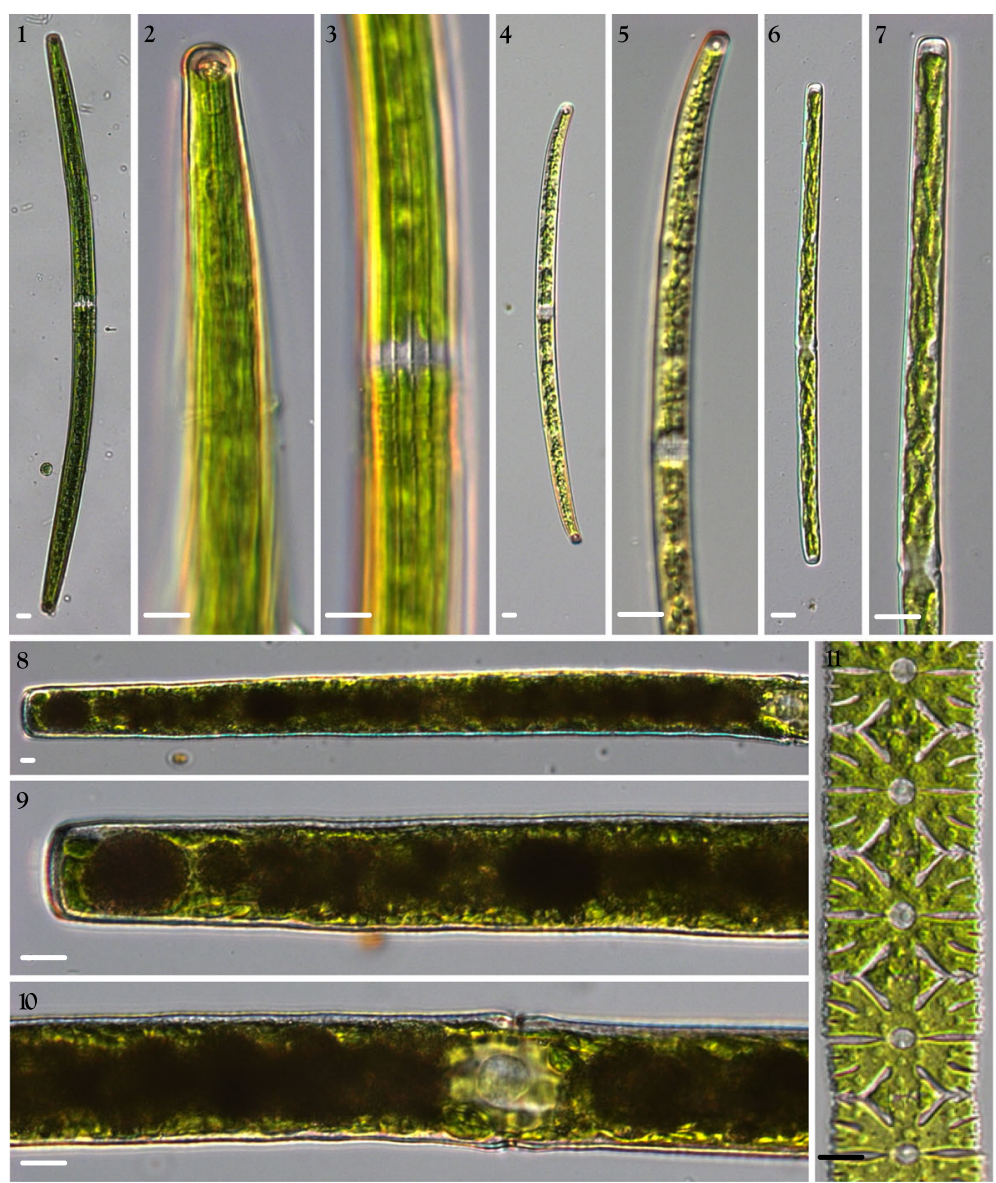

Plate 5 Figs. 1-3 Closterium angustatum. 4, 5 Closterium juncidum. 6, 7 Haplotaenium minutum var. elongatum. 8-10 Pleurotaenium simplicissimum. 11 Micrasterias foliacea

Cell small, as long as broad, median constriction deep, sinus narrowly linear, slightly open at extremity; semicells elliptic, lateral margins convex, basal angle rounded, apex flat to slightly convex, margins granular-undulate, elliptic with 3 large granules in middle of each side in vertical view, subcircular in lateral view; cell wall ornamented with 5 to 6 vertical series of emarginated granules, protruded midregion with 3 vertical series of 3-4 granules per row. Cell length 25$28 \mu \mathrm{m}$, breadth $25-28 \mu \mathrm{m}$, isthmus $6-7 \mu \mathrm{m}$.

\section{Cosmarium reniforme var. elevatum W. \& G.S. West}

\section{(Plate 3, Figs. 15-17)}

Prescott et al. 1981. p. 277. Pl. 259, Fig. 1; Yamagishi and Akiyama 1985, 4: 27.

Cell medium in size, about 1.5 times longer than broad, median constriction deep, sinus narrow linear, slightly dilated extremity; semicells reniform, apex elevated, basal angles rectangular-rounded, lateral margins slightly convex, ellipsoid in lateral view, broadly elliptic in vertical view; cell wall with coarse granules arranged in regular, longitudinal rows. Cell length $50-52 \mu \mathrm{m}$, breadth $30-32 \mu \mathrm{m}$, isthmus $10-11 \mu \mathrm{m}$.

\section{Cosmarium stigmosum (Nordstedt) Krieger (Plate 3, Figs.} 18 and 19)

Krieger and Gerloff 1969, p. 169, Pl. 35, Fig. 1; Yamagishi and Akiyama 1987. 6, 27.

Cell medium in size, about 1.2 times longer than broad, median constriction deep, sinus narrow, open outward; Semicells trapeziform, basal angle rounded, apex flat to slightly convex, lateral margin convex, apical angles broadly rounded; hexagonal-elliptic with poles broadly rounded in vertical view; subcircular in lateral view; cell wall with fine granules. Cell length $39-41 \mu \mathrm{m}$, breadth $32-34 \mu \mathrm{m}$, isthmus $14-15 \mu \mathrm{m}$.

\section{Xanthidium cristatum var. papilliferum Irénée-Marie}

(Plate 1, Figs. 6-9)

Prescott et al. 1982. p. 65. Pl. 321, Fig. 1.

Cell large, slightly longer than broad (excluding spines), median constriction deep, sinus narrowly linear, slightly open extremity; semicells subpyramidal, apices truncate, 

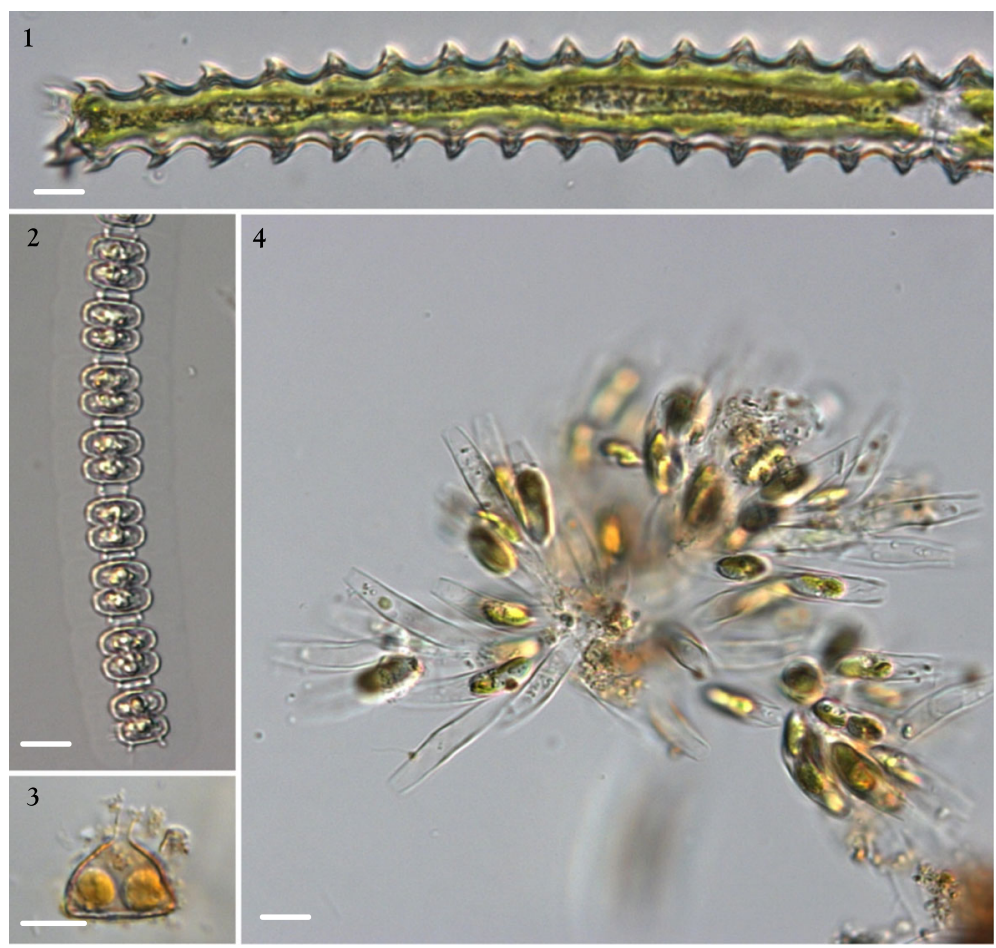

Plate 6 Fig. 1 Triploceras gracile. 2 Onychonema filiforme. $\mathbf{3}$ Lagynion triangulare. $\mathbf{4}$ Epipyxis ramosa

lateral margins concave, lateral and apical angles with pairs of spines upwardly directed, basal angles with a spine horizontally directed and a single wart (Plate 1, Fig. 6, arrow), midregion protuberance bearing a ring of 8-12 pits surrounding a series of $2-3$ pores, elliptic with a small protuberance at midregion on each side and 3 divergent spines at each pole in vertical view, circular with a small midregion protuberance on each side and a pair of divergent spines at apical margin in lateral view. Cell length 45-48 $\mu \mathrm{m}$ excluding spines, $61-65 \mu \mathrm{m}$ including spines, breadth $42-45 \mu \mathrm{m}$ excluding spines, isthmus $10-11 \mu \mathrm{m}$, spine length $7-10 \mu \mathrm{m}$.

\section{Xanthidium octocorne Ralfs (Plate 4, Figs. 1 and 2)}

West and West 1912, p. 3, Pl. 117, Figs. 6-10; Coesel and Meesters K(J). 2007, p. 155, Pl. 85, Figs. 9-11.

Cell small, about 1.3 longer than broad (excluding spines), median constriction deep, sinus wide, almost semicircular excavation; semicells transversely trapeziform-rectangular, basal margins slightly concave or straight, sides concave, basal and upper angles rectangularly rounded and with long, acute, straight spines; spines of basal angles parallel to slightly divergent, spines of upper angles divergent, apical margin distinctly concave than the lateral margins, subcircular to ovate in lateral view, elliptic with angles rounded and a straight spine in vertical view. Cell length
17-20 $\mu \mathrm{m}$ excluding spines, $22-24 \mu \mathrm{m}$ including spines, breadth 11-13 $\mu \mathrm{m}$ excluding spines, isthmus $4-5 \mu \mathrm{m}$, spine length $5-7 \mu \mathrm{m}$.

\section{Staurastrum arachne Ralfs (Plate 4, Figs. 5-8)}

Hirano 1959. p. 366, Pl. 47, Fig. 10; Prescott et al. 1982. p. 127. Pl. 429, Fig. 5; Pl. 432, Figs. 3 and 9; Coesel and Meesters K(J). 2007, p. 174, Pl. 107, Figs. 1-3.

Cell small, about two times as long as broad with processes, median constriction deep, sinus an acute notch, open toward apex, isthmus narrow; semicells cup-shaped, apical margins slightly convex, lateral angles extended into relatively slender horizontal process terminated by $3 \mathrm{~min}$ spines; dorsal margin crenulate, ventral margin smooth, arms horizontal, with 4 series of minute encircling denticulations and with a horizontal series of minute spines above the isthmus, 5-radiate, sides concave, internal region of sides with one minute sharp spine, central area smooth, angles with processes tipped with 3 min teeth in vertical view. Cell length $20-22 \mu \mathrm{m}$, breadth $36-40 \mu \mathrm{m}$ with processes, isthmus 9-11 $\mu \mathrm{m}$.

\section{Staurastrum cyrtocerum var. inflexum Coesel \& Meesters (Plate 4, Figs. 3 and 4)}

Coesel and Meesters K(J). 2013. p. 89. Pl. 78, Figs. 3-12. 

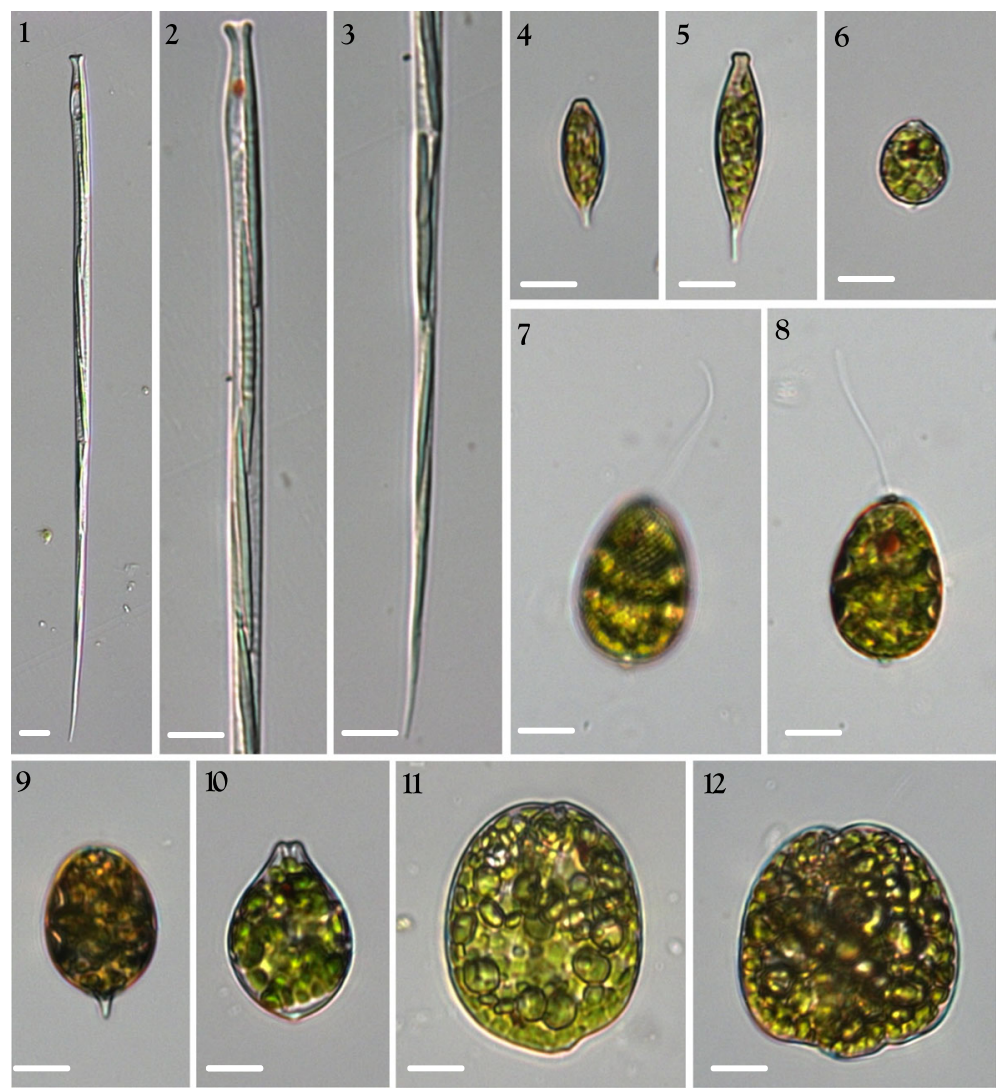

Plate 7 Figs. 1-3 Cyclidiopsis acus. 4 Lepocinclis acicularis. 5 L. marssonii var. sinensis. 6 L. fusiformis var. minor. 7, 8 L. ovum var. palatina. 9 L. pseudoovum. 10 L. fusiformis var. amphirhynchus. 11 Phacus brevicaudatus. 12 P. lefevrei

Cell small, including processes about 1.35 times broader than long, median constriction deep, sinus an acute notch, broadly open, isthmus relatively broad; semicells subcuneate, apical margin slightly convex, ventral margins concave, processes relatively long and nearly horizontal or strongly downturned, with series of 4 transverse granules, tipped with $2-3$ short teeth, triangular with slightly concave margins, truncate processes, margins undulate-granular, smooth in median region of cell in vertical view. Cell length 17-20 $\mu \mathrm{m}$, breadth $27-30 \mu \mathrm{m}$ with processes, isthmus $4-5 \mu \mathrm{m}$.

\section{Staurastrum sexangulare var. productum Nordstedt}

(Plate 4, Figs. 13-15)

Scott and Prescott 1961. p. 107. Pl. 46, Fig. 4.

Cell medium in size, including protuberance about 1.5 times broader than long, median constriction deep, sinus broad and U-shaped, acutely open at the extremity; semicells bowl-shaped, basal margins slightly concave, apical margin convex, lateral margins forming a processes divided into two whorls of subprocesses, lower whorl of subprocesses horizontal or slightly convergent, upper one divergent, each process with 2-3 series denticulations at

Table 2 Morphological characteristics of Cosmarium hexagonm sp. nov. and related taxa

\begin{tabular}{|c|c|c|c|c|c|}
\hline & C. hexagonum sp. nov. & C. praecisum & C. polygonatum & $\begin{array}{l}\text { C. polygonum f. } \\
\text { rectum }\end{array}$ & $\begin{array}{l}\text { C. polygonatum var. } \\
\text { hexagonum }\end{array}$ \\
\hline Semicell shape in front view & Rhomboid & $\begin{array}{l}\text { Transversely } \\
\text { hexagonal }\end{array}$ & Hexagonal & Hexagonal & Broadly hexagonal \\
\hline $\begin{array}{l}\text { Semicell shape in vertical } \\
\text { view }\end{array}$ & Octagonal & Ellipsoid & Ellipsoid & Ellipsoid & Ellipsoid \\
\hline Wall scrobiculation & $\begin{array}{l}\text { Median conical } \\
\text { tubercles }\end{array}$ & Median tubercles & $\begin{array}{l}\text { Median } \\
\text { tubercles }\end{array}$ & $\begin{array}{l}\text { Median conical } \\
\text { tumor }\end{array}$ & $\begin{array}{l}\text { Median tumor and one } \\
\text { small granule at each angles }\end{array}$ \\
\hline Cell length & $25-27 \mu \mathrm{m}$ & $13-18 \mu \mathrm{m}$ & $8-14 \mu \mathrm{m}$ & $14 \mu \mathrm{m}$ & $9.2-9.9 \mu \mathrm{m}$ \\
\hline Cell broad & $24-25 \mu \mathrm{m}$ & $13-19 \mu \mathrm{m}$ & 9-17 $\mu \mathrm{m}$ & $12.5 \mu \mathrm{m}$ & $9.2 \mu \mathrm{m}$ \\
\hline Isthmus & $5-6 \mu \mathrm{m}$ & $3-6 \mu \mathrm{m}$ & $3.5-5 \mu \mathrm{m}$ & $4 \mu \mathrm{m}$ & $2.5 \mu \mathrm{m}$ \\
\hline
\end{tabular}


the side and 3-4 spines at the extremity, 5-radiate, angles produced to form the long tapering processes, upper whorl of subprocesses from base of lower one, sides concave and with two pairs of small granules at base of each processes, midregion smooth in vertical view. Cell length 35-37 $\mu \mathrm{m}$, breadth 55-58 $\mu \mathrm{m}$ with processes, isthmus 9$10 \mu \mathrm{m}$. This variety differs from type species by a pair of granules between processes, and two pairs of minute granules at base of each processes.

Staurastrum sinense Lütkemüller (Plate 4, Figs. 9-12) Prescott et al. 1982. p. 190, Pl. 340, Figs. 1 and 2; Coesel and Meesters K(J). 2013, p. 149, Pl. 54, Figs. 11 and 12.

Cell small, about as long as broad with processes, median constriction deep, sinus a broad U-shaped, widely open; semicells broadly cuneiform, apical margin truncate or nearly straight, apical angles produced to form cylindrical processes, with $4-5$ or more concentric series of fine granules, 4-radiate, sides concave, pronounced, broadly rounded to truncate angles, central area smooth in vertical view. Cell length $20-25 \mu \mathrm{m}$, breadth $20-$ $25 \mu \mathrm{m}$ with processes, isthmus $8-10 \mu \mathrm{m}$.

\section{Desmidium baileyi var. caelatum (Kirchn.) Nordstedt}

(Plate 1, Figs. 10-12)

Coesel and Meesters K(J). 2007, p. 210, Pl. 123, Figs. 1-4.

Cell slightly broader than long, median constriction very shallow, widely open; semicells rectangular, lateral margins parallel, apical margin markedly concave, 3 or 4 angular sides with rounded angles, straight or slightly concave in vertical view; filaments slightly twisted or not twisted. Cell length $17-20 \mu \mathrm{m}$, breadth $20-25 \mu \mathrm{m}$.

\section{Onychonema filiforme (Ralfs) Roy \& Bisset (Plate 6, Fig. 2) (Syn.: Sphaerozosma filiforme Ralfs)}

Coesel and Meesters K(J). 2007, p. 207, Pl. 120, Figs. 5-7; Dillard 1993, p. 122, Pl. 35, Fig. 1. John et al. 2011, p. 739, Pl. 179, Fig. D.

Cell as long as broad or slightly broader than long; median constriction deep, sinus narrow linear; semicells ellipsoid or semicircular, apical margin slightly convex; apical processes about $1 / 2$ of semicell length, widely spaced and disposed asymmetrically, one overlapping adjacent cell in front, the other behind; wall smooth. Cell length 10-13 $\mu \mathrm{m}$, breadth $13-14 \mu \mathrm{m}$, isthmus 4$5 \mu \mathrm{m}$. This species was reported by Chung et al. at Han River in 1968, and illustrated as O. filiformis in Illustrated Encyclopedia of Fauna and Flora of Korea (Chung 1968), but cell shape of that specimen differs considerably from type species.

Micrasterias foliacea Bailey ex Ralfs (Plate 5, Fig. 11)

Prescott et al. 1977. p. 158. Pl. 139, Figs. 3-8.
This species reported by Chung et al. only as list at Seoul and Chuncheon in 1965 and 1968, respectively, but it has not been reported in Korean peninsula until observed at very shallow wetland of Jeju Island by Kim (2014a).

Triploceras gralile Bailey ex Ralfs (Plate 6, Fig. 1)

Prescott et al. 1975. p. 143. Pl. 51, Figs. 7-14; Dillard 1990, p. 140, Pl. 49, Fig. 6.

Reported by Kim (2014b) in a very shallow wetland on Jeju Island, but very rare and new to Korean peninsula.

\section{Euglenophyta}

I identified 49 taxa in the Euglenophyta, 9 of which are new to Korea.

\section{Cyclidiopsis acus Korshikov (Plate 7, Figs. 1-3)}

Huber-Pestalozzi 1955, p. 405, Pl. 83, Fig. 869; Yamagishi and Akiyama 1995. 14:19.

Cell colorless, free-swimming, osmotrophic, elongated, tapering, rigid, slight bending, no euglenoid movement; similar to Euglena acus except for apical canal opening. Cell length 130-190 $\mu \mathrm{m}$, breadth $6-13 \mu \mathrm{m}$.

\section{Lepocinclis acicularis Francé 1893 (Plate 7, Fig. 4)}

Yamagishi and Akiyama 1989. 10. 40.

Cell fusiform; anterior end narrow and truncate; posterior end narrowly produced into short, straight cauda; lateral sides slightly convex; periplasts oblique-spirally striated; paramylon two, ring-like plate. Cell length 17$23 \mu \mathrm{m}$, breadth $8-10 \mu \mathrm{m}$.

Lepocinclis fusiformis var. amphirhynchus Nygaard (Plate 7, Fig. 10)

Yamagishi and Akiyama 1998. 20. 42.

Cells broad and fusiform; anterior end conically narrowed, produced into a truncately rounded and shallowly bilobed apex; posterior end conically produced into a short caudal process; lateral sides roundly swelled; periplasts spirally striated; paramylon two, ring-like plate. Cell length $25-28 \mu \mathrm{m}$, breadth $20-23 \mu \mathrm{m}$.

\section{Lepocinclis fusiformis var. minor Chu (Plate 7, Fig. 6)}

Yamagishi and Akiyama 1994. 13. 24.

Cell small, broad and fusiform; anterior end narrow and truncate; posterior end bluntly rounded and slightly pronounced, with a small nipple-like process; lateral sides broadly convex; periplasts spirally striated; paramylon two, ring-like plate. Cell length $16-18 \mu \mathrm{m}$, breadth $12-14 \mu \mathrm{m}$.

Lepocinclis marssonii var. sinensis Popova (Plate 7, Fig. 5)

Yamagishi and Akiyama 1989. 10. 40. 
Cell long and fusiform; anterior end narrowly produced, with neck-like constriction and truncate, slightly bipapillated; posterior end gradually narrow and projected into a straight cauda, with a distinct nodulation at base; lateral sides convex; periplasts longitudinally striated; paramylon two, ring-like plate. Cell length 35$42 \mu \mathrm{m}$, breadth $9-11 \mu \mathrm{m}$.

Lepocinclis ovum var. palatina Lemmermann (Plate 7, Figs. 7 and 8)

Yamagishi and Akiyama 1997. 19. 33.

Cell broad ovoid, broadest at posterior end; anterior end gradually narrowed, rounded, shallowly bilobed; posterior end broad truncately rounded, with a small papillate cauda; periplasts spirally striated; paramylon two, ring-like plate. Cell length $30-33 \mu \mathrm{m}$, breadth 20 $25 \mu \mathrm{m}$.

\section{Lepocinclis pseudoovum Conrad (Plate 7, Fig. 9)}

Yamagishi and Akiyama 1989. 10. 48.

Cell ovoid to broad ellipsoid; anterior end broadly rounded or slightly truncate; posterior end broad rounded, with a short, straight cauda; periplasts spirally striated; paramylon two, ring-like plate. Cell length 30$33 \mu \mathrm{m}$, breadth $20-22 \mu \mathrm{m}$, cauda $3-4 \mu \mathrm{m}$.

\section{Phacus brevicaudatus (Klebs) Lemmermann (Plate 7, Fig. 11)}

Yamagishi and Akiyama 1994. 13. 40.

Cell large, thick, broad ovoid, nearly suborbicular in face view; dorsal surface with a longitudinal, deep furrow extending the full length of the cell; thin ellipsoid with a concave absence at one side in vertical view; anterior end narrowly rounded and shallowly bilobed; posterior end broadly rounded, with an abbreviated obtuse cauda-like projection; lateral sides broadly swelled; periplasts roughly and longitudinally striated; paramylon one or two, large, ring-like or circular plate. Cell length 45$50 \mu \mathrm{m}$, breadth $30-32 \mu \mathrm{m}$.

\section{Phacus lefevrei Bourrelly (Plate 7, Fig. 12)}

Yamagishi and Akiyama 1987. 7. 50.

Cell large, broad ovoid to subcircular; anterior end slightly narrow and rounded, shallowly bilobed by a dorsal furrow; posterior end broadly rounded with a short round projection; lateral sides broadly rounded with periplasts, roughly and longitudinally striated; paramylon a single large circular plate. Cell length $44-47 \mu \mathrm{m}$, breadth $42-45 \mu \mathrm{m}$.

\section{Chrysophyta}

I identified 53 taxa in the Chrysophyta, 3 of which are new to Korea.
Tetraedriella polychloris Skuja (Plate 1, Fig. 3)

John et al. 2011, p. 332, Pl. 85, Fig. D.

Cells free-floating, tetrahedral, with slightly convex to concave sides and broadly rounded angles, rounded corners without spines; cell wall fairly thick and ornamented with coarse punctate; chloroplast numerous, small discoid, without pyrenoid; Cell diameter 25-30 $\mu \mathrm{m}$.

\section{Epipyxis ramosa (Lauterborn) Hilliard \& Asmund (Plate 6, Fig. 4)}

(Syn.: Hyalobryon ramosum Lauterborn)

Yamagishi and Akiyama 1985. 4. 41; John et al. 2011. p. 297. Pl. 77. Fig. K.

Thallus epiphytic, dendroid colony; lorica long and cylindrical, slightly curved or twisted, base conically rounded, margins parallel. Cell length $40-50 \mu \mathrm{m}$, breadth $3.5-6.5 \mu \mathrm{m}$.

\section{Lagynion triangulare (Stokes) Pascher (Plate 6, Fig. 3)}

Dillard 2007. p. 9. Pl. 1, Fig. 13.

Thallus epiphytic, unicellular; lorica flask-shaped with angular corner and base flattened against substrate; neck long and cylindrical; one or two small discoid chromatophores. Lorica diameter 16-18 $\mu \mathrm{m}$, height 11-12 $\mu \mathrm{m}$; neck length $4-5 \mu \mathrm{m}$, diameter $2-2.5 \mu \mathrm{m}$.

\section{Discussion}

Previous studies have reported about 2450 taxa of freshwater algae in Korea excluding diatoms (Kim 2015; Lee and Kim 2015a, 2015b; Lee and Kim 2015a, 2015b; Kim 2017; Kim and Kim 2017; Jung et al. 2017). We identified one new species-Cosmarium hexagonum sp. nov.-and provide the first report of 44 phytoplankton taxa in Korea.

The phytoplankton community of Cheonjin Lake has high species diversity, especially desmids, and the number of species was greatest during the autumn. Previous investigations in swamps or in old and shallow reservoirs of Korea have reported similar results (Kim and Chung 1993a, 1993b; Kim 2001). Cheonjin Lake appeared to have a greater abundance of phytoplankton than other brackish lagoons in Korea. Several previous studies have examined phytoplankton flora in lagoons of Korea. In particular, the phytoplankton communities of these lagoons had 15 to 164 taxa, with a high abundance of diatoms (Cho et al. 1975; Mizuno and Cho 1980; Lee et al. 2000; Moon and Lee 2002; Heo et al. 2004; Kwon et al. 2005). However, the phytoplankton flora in Cheonjin Lake, which recently changed to freshwater, were characterized by a high abundance of desmids and chlorococcal green algae and relatively low abundance of diatoms, in contrast to the previously surveyed brackish lagoons, lakes, reservoirs, and swamps in Korea. In fact, the phytoplankton community of Cheonjin Lake was very similar to that of shallow reservoirs and swamps at inland locations, in that there 
was a high species diversity and many species of desmids, but few taxa in the Euglenaceae (Kim and Chung 1993a, 1993b). In addition, this lake has 44 taxa, including one new species, that are new to Korea.

In conclusion, this study of changes in a phytoplankton community in a region that changed from lagoon to brackish water and then to freshwater provides important new information about ecological succession in an aquatic community.

\section{Conclusion}

In this study, a total 376 taxa of 148 desmids (Charophyceae), Chlorophyceae (103 taxa), Chrysophyta (53 taxa), Euglenophyta (49 taxa), Cyanophyta (13 taxa), Dinophyta ( 8 taxa), and Chryptophyta (2 taxa) were identified from Cheonjin Lake. Twenty-eight taxa of desmids including a new species (Cosmarium hexagonum sp. nov.), 9 taxa of Euglenophyceae, 4 taxa of Chlorophyceae, 2 taxa of Chrysophyceae, and 1 taxon of Xanthophyceae were newly recorded in Korea.

\section{Abbreviations}

Fig.: Figure; Pl.: Plate; Syn.: Synonym

\section{Acknowledgements}

This work was supported by a grant from the National Nakdong River Institute of Biological Resources (NNIBR) and the National Institute of Biological Resources (NIBR) and funded by the Ministry of Environment (MOE) of the Republic of Korea (NNIBR20160002, 20170002, and NIBR201701209).

\section{Availability of data and materials}

Not applicable

\section{Author's contributions}

The author conceived the study, collected the data, interpreted the results, and wrote the manuscript. The author read and approved the final manuscript.

\section{Ethics approval and consent to participate}

Not applicable

\section{Consent for publication}

Not applicable

\section{Competing interests}

The author declares no competing interests.

\section{Publisher's Note}

Springer Nature remains neutral with regard to jurisdictional claims in published maps and institutional affiliations.

Received: 18 August 2018 Accepted: 8 October 2018

Published online: 22 November 2018

\section{References}

Brook AJ. The biology of desmids. Botanical monographs, vol. 16. Berkeley and Los Angeles: California University Press; 1981. p. 276.

Brook AJ, Williamson DB. A monograph on some British desmids. The Ray Society. London: U.K; 2010. p. 364

Cho KS, Hong SU, Ra KH. The comparative study of limnological conditions and plankton fauna of brackish water in the east coast of Korea. Kor J Limnol. $1975 ; 8: 25-37$
Cho KS, Park YS. Limnological studies of the Young-nang lake. Kor J Limnol. 1969; 2:51-66.

Chung J. A study of the Euglenophyceae from Chun La book do area. Res Rev KNU. 1975;20:233-42

Chung J. A study on the Cyanophyceae from Chun La Book Do area. Kor J Bot. 1976;19:19-30.

Chung J. A study on the fresh-water algae from Chungchong Book Do area. Kor J Limnol. 1979;12:41-53.

Chung J, Kim SD, Lee KS. Fresh-water algae from Jaeju Island (1). Kor J Limnol. 1972a;5(1-2):13-28.

Chung J, Kim SD, Lee KS. Fresh-water algae from Jaeju Island (2). Kor J Limnol. $1972 b ; 5(3-4): 15-31$.

Chung YH. Illustrations of the Korean animal and plant, vol. Vol. 9. Samhwa Pub, Seoul: Plantae (Freshwater algae); 1968. p. 573.

Chung YH, Kay ES, Park DW. A study on the microflora of the Han River (II). Kor J Bot. 1968;11:1-30.

Chung $\mathrm{YH}$, Lee OM. A taxonomic study of desmids on several lowland swamps in Haman. Proc Coll Nat Sci SNU. 1986;11:51-98.

Coesel PFM, Meesters K(J). Desmids of the lowlands. Zeist, the Netherlands: KNNV Publishing; 2007. p. 351.

Coesel PFM, Meesters K(J). European Flora of the desmid genera Staurastrum and Staurodesmus. Zeist: KNNV Publishing; 2013. 357 pp.

Croasdale H, Flint EA. Flora of New Zealand: Freshwater Algae, Chlorophyta, Desmids: with ecological comments on their habitats. II. Actinotaenium, Cosmarium, Cosmocladium, Spinocosmarium, Xanthidium. Christchurch: Botany Division. DSIR; 1988. p. 147.

Dillard GE. Freshwater algae of the southeastern United States. Part 3. Chlorophyceae: Zygnematales: Desmidiaceae (section 1). Bibliotheca Phycologica, vol. 85. Berlin. Stuttgart: J Cramer; 1990. p. 172.

Dillard GE. Freshwater algae of the southeastern United States. Part 4. Chlorophyceae: Zygnematales: Desmidiaceae (section 2). Bibliotheca Phycologica, vol. 89. Berlin. Stuttgart: J Cramer; 1991. p. 205.

Dillard GE. Freshwater algae of the southeastern United States. Part 6. Chlorophyceae: Zygnematales: Desmidiaceae (section 4). Bibliotheca Phycologica, vol. 93. Berlin. Stuttgart: J Cramer; 1993. p. 166.

Dillard GE. Freshwater algae of the Southeastern United States. Part 8. Chrysophyceae, Xanthophyceae, Cryptophyceae and Dinophyceae. Berlin. Stuttgart: Bibliotheca Phycologica 112. J Cramer; 2007. p. 126.

Heo WM, Kwon SY, Lee JI, Kim DJ, Kim BC. The limnological survey of a coastal lagoon in Korea (3). Kor J Limnol. 2004;37:12-25.

Hirano M. Flora Desmidiarum Japonicarum (No. 1). Contributions from the Biological Laboratory Kyoto University. 1955;1:1-56.

Hirano M. Flora Desmidiarum Japonicarum (No. 3). Contributions from the Biological Laboratory Kyoto University. 1957;4:106-65.

Hirano M. Flora Desmidiarum Japonicarum (No. 6). Contributions from the Biological Laboratory Kyoto University. 1959;9:301-86.

Hong SU, Cho KS, Ra KH. Studies on the chemicalconditions and plankton in the Hwajin-po lake. Kor J Limnol. 1969;2:35-42.

Huber-Pestalozzi G. Das Phytoplankton des Süßwassers, Systematik und Biologie, 4. Teil: Euglenophyceen. In: Thienemann A, editor. Die Binnengewässer 16(4). Stuttgart: Schweiz Verg; 1955. p. 606

John DM, Whitton BA, Brook AJ. The freshwater algal flora of the British Isles. Cambridge: Cambridge University Press; 2011. 878 pp

Jung HC, Lee NJ, Kim DH, Lee OK. Four newly recorded taxa of charophytes and chlorophytes (Charophyta and Chlorophyta, Viridiplantae) in Korea. Kor J Environ Biol. 2017;35:289-95.

Kim HS. Desmids (Staurastrum and Staurodesmus) from Kyungsangnam-do. Korea Nova Hedwigia. 1996;62:521-41.

Kim HS. Silica-scaled chrysophytes (Synurophyceae) in several reservoirs, swamps and a highland pond from Changnyong county. Korea Algae. 1997;12:1-10.

Kim HS. Seasonal changes of phytoplankton community in the Woopo and Mokpo swamp. Kor J Limnol. 2001;34:90-7.

Kim HS. Anabaena korean sp. nov. (cyanophyceae), a new species, and new record of fresh-water blue-green algae from Korea. J. Ecol Environ. 2013a;36:293-302.

Kim HS. New records of fresh-water green algae (chlorophytes) from Korea. J Ecol Environ. 2013b;36:303-14.

Kim HS. New records of Euglenophyta from Korea. J Ecol Environ. 2013c;36:339-46.

Kim HS. Desmids from Korea; 1. Desmidiaceae 1 (Micrasterias). J. Ecol Environ. 2014a;37:285-98. 
Kim HS. Records of desmids (Chlorophyta) newly found in Korea. J Ecol Environ. 2014b;37:299-313.

Kim HS. National list of species of Korea. Bluegreen algae. Incheon: Nat Ins Biol Res; 2015. p. 75.

Kim HS, Chung J. Ecological study of phytoplankton on some reservoir (Changnyong county). Kor J Limnol. 1993a;26:203-21.

Kim HS, Chung J. Freshwater algal flora of natural swamps in Chnagnyong County. Kor J Limnol. 1993b;26:305-19.

Kim HS, Takahashi E, Chung J. Morphologic and taxonomic studies on scalebearing Chrysophytea from Naktong River Estuary Lake, Pusan, in Korea. Kor J Limnol. 1995;28:87-99.

Kim JH, Kim HS. New records of freshwater algae from Korea. Species Research. 2017;6:224-31.

Kim JH, Park YJ, Kim HS. Silica-scaled chrysophytes (Synurophyceae) from Jeju Island. Nova Hedwigia. 2009:89:201-18.

Kim YJ. New recorded of several taxa in freshwater algae South Korea. Kor J Environ Biol. 2017:35:305-18.

Kim YS, Choi JS, Kim HS. Epiphytic diatom communities from two mountain bogs in south. Nova Hedwigia. 2007;84:363-79.

Komárek J, Fott B. 1983. Chlorophyceae (Grunalgen) Ordnung: Chlorococcales. In: Das Phytoplankton des Süßwassers. Die Binnengewässer XVI, 7(1) (HuberPestalozzi G). Schweiz Verg, Stuttgart. 1044 pp.

Krieger W, Gerloff J. Die Gattung Cosmarium. Lief. 3/4: 241-410. PIs. 43-71. Weinheim: J Cramer; 1969

Kwon SY, Heo WM, Lee SH, Kim DJ, Kim BC. The limnological survey of a coastal lagoon in Korea (4). Kor J Limnol. 2005;38:461-74.

Lee EJ, Kim HS, Lee KS. Seasonal variation of phytoplankton and environmental factors in Kyungpo Lake. Kor J Environ Biol. 2000;18:95-104.

Lee JB, Kim HS. National list of species of Korea. Flagellates. Nat Ins Biol Res Incheon. 2015:194.

Lee JH, Joh KJ. National list of species of Korea. Diatoms. Nat Ins Biol Res Incheon. 2015:365.

Lee OM, Kim JH. National list of species of Korea. Green algae. Nat Ins Biol Res Incheon. 2015:307.

Mizuno T, Cho KS. Paleolimnological study from the present status of the lake Hwajin-po and Yeong-rang. Kor J Limnol. 1980;13:17-22.

Moon BY, Lee OM. The distribution and standing crop of phytoplankton of lagoons in the east coast of Korea. Kor J Environ Biol. 2002;20:325-38.

Prescott GW. Algae of the Western Great Lakes area. lowa: WM. C. Brown Company Publisher; 1962 . p. 977.

Prescott GW, Croasdale HT, Vinyard WC. A synopsis of north American desmids Part II. Desmidiaceae: Placodermae Section 1. Lincoln: Nebraska University Press; 1975. p. 275.

Prescott GW, Croasdale HT, Vinyard WC. A synopsis of north American desmids. Part II. Desmidiaceae: Placodermae Section 2. Lincoln: Nebraska University Press; 1977. p. 413

Prescott GW, Croasdale HT, Vinyard WC. A Synopsis of North American Desmids. Part II. Desmidiaceae: Placodermae Section 4. Lincoln: University of Nebraska; 1982. p. 700

Prescott GW, Croasdale HT, Vinyard WC, Bicudo CEM. A Synopsis of North American Desmids. Part II. Desmidiaceae: Placodermae Section 3. Lincoln: University of Nebraska; 1981. p. 720.

Scott AM, Prescott GW. Indonesia desmids. Hydrobiol. 1961;17:1-132 pls. 1-63.

West W, West GS. A monograph of the British Desmidiaceae. London: Ray Society; 1912. p. 204

Wui IS, Kim BH. The Flora of the fresh-water algae in Chol La Nam Do, Korea (I) Euglenophyceae. Kor J Phycol. 1987a;2:119-27.

Wui IS, Kim BH. Flora of the fresh-water algae in Chol La Nam do, Korea (II) Cyanophyceae. Kor J Phycol. 1987b;2:193-201.

Yamagishi T, Akiyama M. 1985, 1986, 1987, 1989, 1994, 1995, 1997, 1998. Photomicrographs of the fresh-water algae. Tokyo: Uchida Rokakuho; 1984

Ready to submit your research? Choose BMC and benefit from:

- fast, convenient online submission

- thorough peer review by experienced researchers in your field

- rapid publication on acceptance

- support for research data, including large and complex data types

- gold Open Access which fosters wider collaboration and increased citations

- maximum visibility for your research: over $100 \mathrm{M}$ website views per year

At BMC, research is always in progress.

Learn more biomedcentral.com/submissions 